\title{
Artistas latino-americanos na Paris modernista: a difícil consagração'
}

Latin American artists in modernist Paris: a difficult consecration

https://doi.org/10.1590/1982-02672021v29e17

\author{
ANA PAULA CAVALCANTI SIMIONI² \\ https://orcid.org/0000-0002-9305-6139 \\ Universidade de São Paulo / São Paulo, SP, Brasil
}

RESUMO: Este artigo busca problematizar as possibilidades de reconhecimento obtidas por artistas latino-americanos na Paris modernista. A partir das teorias sobre consagração artística, analisa-se principalmente o processo de musealização das obras de artistas latino-americanos que passaram a compor os acervos públicos franceses entre a década de 1910 e a fundação do Musée National d'Art Moderne, em 1947. A pesquisa realizada nos Archives Nationales permitiv identificar quantos e quais, dentre os mais de trezentos artistas latino-americanos atuantes em Paris, foram escolhidos para comporem tais coleções. Como se verá, foram realmente poucos aqueles que conseguiram ter suas obras inseridas numa coleção pública francesa, e mesmo assim, isso não garantiu visibilidade na época, como as flagrantes ausências no MNAM bem revelam.

PALAVRAS-CHAVE: Artistas latino-americanos. Modernismo. Paris. Musealização. Musée National d'Art Moderne.

ABSTRACT: This article seeks to problematize the recognition possibilities of Latin American artists in modernist Paris. Based on theories of artistic consecration, this article analyzes the process of musealization of works by Latin American artists, who became part of French public collections between the 1910s and the founding of the Musée National d'Art Moderne in 1947. The research,

\begin{abstract}
1. Esta pesquisa contou com apoio da Fapesp (16/032446) e da Fondation Maison des Sciences de l'Homme.

2. Possui graduação em Ciências Sociais pela Universidade de São Paulo (USP), mestrado e doutorado em Sociologia pela mesma instituição. Fez doutorado-sandwich na École des Hautes Études en Sciences Sociales, Paris. É docente do Instituto de Estudos Brasileiros (USP) e professora colaboradora do programa de pós-graduação Interunidades Estética e História da Arte (MAC-USP), onde orienta atualmente alunos de doutorado. Membro do Institut d'Études Avancées de Nantes (2021-24). É líder do grupo de pesquisa Gênero, Arte, Artefato e Imagens (GAAI). E-mail: <anapcs@usp.br>.
\end{abstract}


carried out in the Archives Nationales, made it possible to identify how many and which, among the more than three hundred Latin American artists who developed their work in Paris, were chosen to become part of these collections. As we will see, only a minuscule few actually managed to have their works included in a French public collection. Even when they did, this was hardly a guarantee of visibility, as revealed by certain blatant absences in the MNAM collection.

KEYWORDS: Latin American artists. Modernism. Paris. Musealization. Musée National d'Art Moderne. 
Uma visita hoje ao Centre Pompidou, sede atual do Musée National d'Art Moderne da França, permite que o público admire um dos mais conhecidos autorretratos de Frida Kahlo, pintura que está frequentemente em destaque no percurso expositivo. ${ }^{3}$ Por sinal, a visibilidade dos artistas originários da América Latina foi propositalmente frisada na exposição "Modernités Plurielles" levada à cabo por essa instituição, entre 2013 e 2015, sob a curadoria de Catherine Grenier. Nessa polêmica exposição, o modernismo brasileiro foi alçado a uma centralidade incomum nas narrativas internacionais sobre arte moderna, chegando mesmo a protagonizar um dos núcleos centrais da mostra, intitulado "Os Realismos". ${ }^{4}$ No entanto, essa centralidade, ou esse reconhecimento, nem sempre estiveram presentes na instituição, como pretendo discutir nas próximas páginas.

Desde meados do século XIX Paris se consolidou como metrópole artística, atraindo milhares de artistas estrangeiros. ${ }^{5}$ Para os artistas latino-americanos de orientação acadêmica, desde ao menos 1860 a chamada "Cidade Luz" sobrepujara a importância de Roma como centro preferido para consolidarem suas formações e almejarem algum tipo de reconhecimento internacional. Tal situação não se alterou nas primeiras décadas do século XX, mesmo com a perda de centralidade da academia, e a cidade passou a atrair também artistas de orientação modernista. E isso se manteve ao longo do século XX, ainda que com a Segunda Guerra Mundial Nova lorque tenha despontado como um centro potente, Paris se manteve como um destino importante de latino-americanos. ${ }^{6}$

Diversos estudos já discutiram esse tema. Em Artistas modernistas em Paris, década de 1920, Marta Rossetti Batista analisou minuciosamente as permanências de vários artistas brasileiros na capital francesa durante a década citada.7 Apesar da contribuição inestimável da pesquisa, de seu pioneirismo e dos dados fundamentais mobilizados, a autora exclui do campo analítico os artistas não afinados com as correntes percebidas por ela como de vanguarda. Marcia Camargos soluciona parte de tal lacuna ao dedicar-se ao estudo do Pensionato Artístico do Estado de São Paulo, órgão criado em 1914, cujo papel era fomentar o aprimoramento artístico no exterior de pintores, escultores e musicistas paulistas, muitos deles de orientação mais conservadora. Entre 1914 e 1930, foram outorgadas catorze bolsas para artistas plásticos se aprimorarem em Paris. ${ }^{8} \mathrm{Em}$ pesquisa anterior, abordando também os artistas provenientes de outros estados que não apenas São Paulo, cheguei ao número de 25 artistas brasileiros em Paris, apenas durante os anos 1920.9 Esses trabalhos se dedicaram, especialmente, a recuperar as trajetórias dos artistas na capital francesa, focalizando os locais de formação, os espaços de exposição pelos quais circularam e o modo com que foram percebidos pela crítica e pela historiografia.
3. Cf. <https://bit. $1 \mathrm{y} / 3 \mathrm{r} 3 \mathrm{YH} 3 \mathrm{w}>$.

4. A esse respeito Cf. $<$ https://bit.ly/3r5xcqd>. A exposição não foi consensualmente bem vista, para alguns, muito embora ela tenha tentado criar uma narrativa não eurocêntrica, os princípios estéticos, divisões e critérios utilizados mais reafirmaram o cânone europeu do que o contrário. Nesse sentido, consultar: Mora; Parkmann (2015); Maroja (2013).

5. Em 1860 já se falava de 4 mil artistas atuantes na cidade, segundo Lethève (1968, p. 178). Ler também Gonnard; Lebovici (2007).

6. Guilbault (1983). Vale, porém, notar que para os artistas latino-americanos Paris manteve sua centralidade relativa durante a segunda metade do século XX. Cf. Couto (2016). Sobre esse tema, ler também Plante (2013).

7. Batista (2012).

8. Todavia, a pesquisa de Márcia Camargos concentra-se no caso dos artistas subvencionados pelo Pensionato Artístico, portanto de origem paulista, isso significa que as viagens dos artistas fluminenses, patrocinadas pela ENBA ou custeados por seus estados, não foram consideradas.

9. Simioni (2016). 
10. Carta de Tarsila para Anita Malfatti, 20 de outubro de 1920. Citada por Amaral (2003, p. 48).
Os três textos mencionados abordam o caso dos artistas brasileiros, especificamente durante as décadas de 1910 e 1920. Já a pesquisa de Michele Greet, Transatlantic encounters: Latin American artists in Paris between the wars, que resultou em um livro e um site, amplia consideravelmente o foco para mais de trezentos artistas provenientes de diversos países da América Latina, que realizaram estadias em Paris entre 1910 e 1940. A autora investiga as condições de formação a que tiveram acesso; as participações nos salões e nas galerias; o modo com que foram percebidos pela crítica; e o nível de reconhecimento alcançado. $\bigcirc$ presente artigo dialoga com tais pesquisas procurando, porém, avançar em um dado que foi pouco investigado, ou pouco destacado, pelas autoras citadas: a presença das obras latinoamericanas nas coleções museais francesas no período em questão.

Os artistas latino-americanos não formaram um grupo coeso ou uma escola. Nesse sentido, diferiram de outras colônias de artistas estrangeiros, como os russos, conhecidos por sua produção junto aos ballets de Diaghilev, pelas obras construtivistas e agrupados em torno de academias privadas, como a Académie de La Palette; ou dos italianos, que ao menos duas vezes organizaram mostras em galerias procurando promover sua visibilidade, tal como Peintres italiens de Paris, no Salon de I'Escalier (em 1928), e Un group d'italiens de Paris, na Galerie Zak (em 1929). Em uma época em que o pertencimento a grupos era um critério significativo para a notabilização no meio, como bem evidenciam os manifestos cuja proliferação se devia à importância de explicitarem um determinado partido estético, o fato de não se destacarem como grupo pode ter constituído um óbice em termos de reconhecimento. Num universo altamente concorrencial, no qual, como bem lembra Tarsila, "eram muitos os chamados mas pouco são os eleitos", 10 consolidar um nome e uma carreira eram desafios não negligenciáveis.

A dificuldade em identificar uma escola latino-americana espelha uma questão maior, a saber, o que se entende por América Latina. A própria noção é bastante complexa, ora definindo-se a partir de uma certa unidade geográfica, que aglutina diversos países abaixo dos Estados Unidos (México, países América Central, da América do Sul e alguns países do Caribe); ou ainda mais histórica uma vez que tais países passaram por processos de colonização impetrados contra suas populações nativas, os quais implicaram certas afinidades linguísticas, pois, de modo geral, trouxeram consigo a imposição do espanhol e do português como línguas nacionais; havendo exceções pontuais como a imposição do francês e inglês em alguns países e até mesmo do holandês no caso Suriname. É também um termo muitas vezes usado em um sentido "distintivo", em contraposição aos países da América do Norte, como os Estados Unidos e o Canadá; contraposição essa derivada de processos coloniais diversos, que trouxeram consigo outras línguas 
(inglês e francês) e religiões, mesmo que de matrizes cristãs, mas não católicas, como prevaleceu nos impérios espanhol e português. No entanto, esse caráter distintivo não espelha apenas diferenças, mas também desigualdades, pois às noções de América do Norte e de América Latina associam-se a representações muito distintas sobre graus de "civilização", modernização e desenvolvimento.

Neste sentido, é interessante ver que América Latina foi também um termo cunhado e "desejado" pelos próprios atores latino-americanos em busca de projetos de identidade, emancipação e valorização que despontaram em diversos momentos ao longo dos séculos XIX e XX. " É preciso sublinhar que, no período aqui estudado, essa noção não estava pronta, mas sim em construção. $\bigcirc$ sistema artístico participou profundamente desse processo, escolhendo os artistas, as obras e um conjunto de narrativas que identificam o que se pode denominar por "arte latino-americana". ${ }^{12}$ $\bigcirc$ presente artigo analisa as possibilidades de alcançar sucesso artístico na Paris modernista, a partir de duas variáveis: em primeiro lugar a nacionalidade, tendo em vista que o escopo da pesquisa diz respeito aos artistas oriundos de países da América Latina e, em segundo lugar, procura-se refletir se o gênero dos (e das) artistas desempenhou algum tipo de impacto nas chances de reconhecimento.

Mas antes de entrarmos no tema propriamente dito, é preciso explicitar o que se entende por êxito ou sucesso artístico. Alguns autores, especialmente provenientes da sociologia da arte, têm debatido o quanto o sucesso dos artistas não é algo arbitrário, ou exclusivamente derivado de seus talentos individuais. Para tanto tem-se procurado apontar que existem índices relativamente constantes, estáveis e dotados de certa objetividade. É possível mensurar o grau de reconhecimento de um artista por meio de elementos concretos como a presença em coleções (públicas e privadas); em grandes mostras e exposições, as quais podem ser hierarquizadas conforme o local em que ocorrem e/ou por serem individuais ou coletivas; ou ainda por suas participações nos meios de comunicação (jornais, revistas, TV, cinema, sites de internet etc.) e, finalmente, por serem objetos de resenhas ou comentários na literatura especializada. ${ }^{13}$ Tais elementos podem ser codificados e ranqueados, como bem demonstram as listagens produzidas pelo Kunstcompass e Artprice, relativos ao sucesso dos artistas em termos de visibilidade e preço das obras alcançado no mercado secundário, tal como foi estudado e discutido por Alain Quemin. ${ }^{14}$ Já o termo consagração significa o grau de reconhecimento acumulado que determina a aceitação dos artistas e obras pelas instâncias legitimadoras; ${ }^{15}$ ou seja, consagração significa o ponto final, e culminante, do processo de reconhecimento.

Nessa direção, o modelo dos círculos de reconhecimento desenvolvido por Alan Bowness (1989), retomado e corrigido por Nathalie Heinich (1998) e,
11. A esse respeito ler: Soares (2015).

12. Dois pontos interessantes para essa discussão mas que não poderei aprofundar neste momento são, na França, a Exposition d'Art Américain-Latin, ocorrida em 1924 na Maison de l'Amérique Latine, a qual congregou 260 obras, de 42 artistas de orientações artísticas e origens nacionais distintas, provenientes de coleções privadas. A exposição não teve grande impacto mas foi uma iniciativa pioneira. A esse respeito ler: Squeff (2015). Mais importante foi, sem dúvida, o investimento do MoMa nessa direção. Para tanto consultar: COTA JR, Eustáquio Ornelas. A formação da coleção latino-americana do MoMA. São Paulo: Paco Editorial. 2019. O autor demonstra como a categoria "arte latino-americana" foi se formando dentro do MoMa especialmente entre 1939 e 1943. Inicialmente, em 1931, estava atrelada a pintores mexicanos, sem englobar um conjunto maior de artistas ou países. Mas aos poucos isso foi se adensando, em função dos interesses geopolíticos do período, conhecidos como Política de Boa Vizinhança e o papel que as artes, particularmente o MoMA, ocuparam nesse processo.

13. Bowness (1989); Heinich (1998); Rojzman (2005).

14. Quemin (2013).

15. Rojzman (2005, p. 19). 
16. No sistema contemporâneo é possível ombrear os grandes museus a algumas instituições privadas, ou fundações, ou ainda centros culturais que também contam com espaços de visitação abertos, ampla frequentação e que possuem alto grau de visibilidade e legitimação. No Brasil, o Itaú Cultural, Instituto Tomie Ohtake, Inhotim são exemplos. Essas instituições podem cumprir papel semelhante ao dos museus.

17. Furió (2012, p. 41, grifo nosso). posteriormente, por Nuria Peist Rojzman (2005) constitui uma baliza metodológica frutífera. A ideia é que entre a produção da obra, considerada como o tempo zero, e a sua consagração, há um processo de construção de visibilidade, legitimidade e reconhecimento, dimensões que envolvem diversos agentes e instâncias. Inicialmente são os mais próximos aos artistas, seus pares imediatos, grupo que pode compreender outros artistas, amigos críticos e os primeiros colecionadores, que constituem seu primeiro círculo de apoio. Esse "núcleo", como define Nuria Peist, é fundamental por chancelar o produtor simbólica e economicamente, mas possui um baixo poder de legitimá-lo. Ao longo do tempo, o reconhecimento se amplia à medida que a obra vai sendo mais conhecida, analisada, adquirida, exposta por grupos sociais mais distantes do artista no tempo e no espaço (termo aqui compreendido em um sentido sociológico e não geográfico). Assim, a consagração, implica um processo de acúmulo de reconhecimento, cujo ponto final depende da integração das obras e dos artistas que as produziram aos grandes museus. Isso porque essas instituições são apontadas pelos autores citados como aquelas com maior capacidade de legitimar as obras e os/as artistas diante do grande público, além de fornecerem uma visibilidade ampliada deles/as. ${ }^{16}$

Nessa direção o comentário de Vicenç Furió sobre a célebre tela Les demoiselles d'Avignon de Picasso, hoje considerada fundadora do cubismo, é bastante interessante:

A princípios del siglo XX, el reconocimiento del arte de vanguardia empezó en el âmbito privado del mercado. Los museos fueron muy lentos y reacios en aceptar las nuevas formas artísticas. Pero a partir de las décadas de 1950 y, especialmente, de 1960, el arte de vanguardia más transgresor tuvo en el Estado y las instituciones su principal valedor y su más rápido sello de reconocimiento. La historia del importante lugar que ocupan Les demoiselles d'Avignon de Picasso en el desarollo del arte moderno no empieza en 1907, sino en 1939, cuando el Museo de Arte Moderno de Nueva York presentó la obra en una de sus salas. ${ }^{17}$

Partindo de tais postulados sobre a consagração artística e, dentro desse processo, sobre o espaço reservado aos grandes museus de arte, este estudo tomou como eixo central a presença de obras de artistas latino-americanos nas coleções públicas francesas, entre as décadas de 1920 e meados da década de 1940. Aborda, ainda, a integração de obras desses artistas naquele que foi o principal marco de todo um processo de institucionalização da arte moderna na França, a saber: a formação do acervo de obras de arte do Musée National d'Art Moderne, criado inicialmente em 1942, durante a Ocupação Alemã, e oficialmente inaugurado em 1947. 
O LUGAR DOS ESTRANGEIROS NA ESCOLA DE PARIS

Na Paris modernista, a proveniência dos artistas era uma condição significativa e, por vezes, desigual. Muito embora alguns artistas estrangeiros tenham se notabilizado imensamente já antes da Segunda Guerra Mundial, como Pablo Picasso, e com isso ajudaram a divulgar uma certa mitologia da cidade como uma "terra de oportunidades", a realidade para a maior parte dos artistas era bem outra. A condição de estrangeiro era um marcador social concreto, bem como uma condição cambiante, cujo peso sofreu variações durante o longo período designado como modernismo. Ser estrangeiro na cosmopolita Paris da "Belle époque" não era em si um obstáculo, muito diverso do que ocorrera no período pós-Primeira Guerra, marcado pelo acirramento dos nacionalismos e atravessado por uma crise econômica que atingiu, evidentemente, o campo da cultura. Ser estrangeiro - ao que se somam as variáveis de país, de região e de religião - tornava a permanência na França algo complicado ou até mesmo perigoso durante os anos finais da década de 1930, após a invasão nazista. A xenofobia então se transformou em política de Estado, o que afetou inclusive o meio artístico, como bem atestam os estudos de Laurence Bertrand Dorléac que se debruçaram sobre o governo de Vichy. ${ }^{18}$

A hostilidade contra os "de fora" já havia se manifestado mesmo antes da Primeira Guerra Mundial (1914-1918), mais precisamente em 1912, quando o conselheiro municipal parisiense Ladoué endereçou uma carta ao subsecretário de Belas Artes, Léon Bérard, acusando o Salon d'Automne de ter sido invadido por uma arte de qualidade questionável, associada ao cubismo, que, segundo ele, era resultado do impacto negativo causado pela presença dos estrangeiros nos círculos da arte francesa. Tal manifestação provocou diversas reações de apoio na imprensa, como a do crítico Louis Vauxcelles (1870-1943) que associava a má qualidade da arte moderna à influência proveniente do exterior. Outros ainda culpavam o júri do salon, visto como tomado por estrangeiros, pelas características decadentes das obras lá acolhidas e premiadas. ${ }^{19}$

Finda a Primeira Guerra Mundial, o incômodo com os forasteiros não desapareceu por completo, talvez tenha mesmo aumentado. Nesse momento, um fato chama a atenção para o quanto a animosidade se encontrava pulsante. Em 1921, decide-se desmembrar em duas partes o Musée du Luxembourg, que era a instituição que acolhia a arte contemporânea na França, então denominada "art vivant". Por um lado, surgiu o museu dedicado às "Escolas Estrangeiras", doravante chamado de Musée du Jeu de Paume, e, de outro, restava o Musée du Luxembourg, cuja função passava a ser expor apenas as
18. A esse respeito consultar, especialmente, Bertrand Dorléac (1986).

19. Joyeux-Prunel (2007). 
20. Joyeux-Prunel (2017, p. 64).

21. Les Cahiers du Musée Nationale d'Art Moderne (2018, p. 40).

22. Joyeux-Prunel (2017, p. 65).

23. Warnod (1925 apud MUSÉE D'ART MODERNE DE LA VILLE DE PARIS, p. 88 , tradução nossa). No original: "L'École de Paris existe. Plus tard, les historiens d'art pourront, mieux que nous, en definir le caractere et étudier les éléments qui la composent, mais nous pouvons toujours affirmer son existence et sa force attractive qui fait venir chez nous les artistes du monde entier [...]. Peut-on considérer comme indésirable l'artiste pour qui Paris est la Terre promise, la terre bénie des peintres et sculpteurs[...]?"

24. No original: "There are among them great artists, creators who give back more than they take. They pay for the others, the followers, the makers of pastiche, the second hand merchants, so others can remain in place and content themselves with coming to France to study the fine arts, returning home right away to exploit the goods they just have acquired and loyally spread throughout the world the sovereignty of French art". Greet (2018, p. 152-153, tradução nossa).

25. A esse respeito consultar: Kangaslahti (2009, p. 85-111). obras dos artistas nascidos na França, com vistas a realçar a visibilidade da contribuição francesa para o desenvolvimento da arte moderna. ${ }^{20} \mathrm{Em} \mathrm{1930,} \mathrm{o}$ Musée du Jeu de Paume ganharia autonomia administrativa, sendo desvinculado da instituição-mãe. ${ }^{21}$ Ainda durante os anos 1920 outros episódios foram marcantes. Em 1923, o comitê do Salon des Indépendants decidiu expor os artistas por nacionalidade. No ano seguinte, decide-se "separar os franceses dos estrangeiros, os últimos devendo ser reagrupados por nacionalidade ou raça". ${ }^{22}$ Como resultado, diversos artistas estrangeiros importantes como Foujita, Van Dongen, Zadkine, Alice Halicka, entre outros, se desligam do Salon des Indépendants, que teve seu prestígio abalado.

O termo "École de Paris", cunhado pelo crítico André Warnod, em 1925, é um dos principais resultados desse complexo momento. Em dois artigos publicados no mesmo ano, o crítico afirmava a existência do conceito de "Escola de Paris" como um agrupamento de tendências contemporâneas, de caráter antiacadêmico e por vezes como sinônimo de arte independente, para o qual contribuíam artistas de diferentes origens, mas que atuavam na França.

A Escola de Paris existe. Mais tarde os historiadores da arte poderão, melhor que nós, definir seu caráter e estudar os elementos que a compõem, mas nós podemos sempre afirmar sua existência e sua força de atração, que faz vir até nós artistas do mundo todo [...]. Podemos considerar como indesejável o artista para quem Paris é a terra prometida, a terra abençoada dos pintores e escultores [...]? ?23

E, mais adiante, ele detalha a contribuição diferenciada entre essa ampla comunidade artística:

Há entre eles grandes artistas, criadores que devolvem mais do que eles tomam. Eles pagam pelos outros, os seguidores, os fabricantes de pastiche, os comerciantes de segunda mão, para que esses possam permanecer no lugar e se contentarem com a chegada à França para estudar as belas artes, voltando para casa e explorando os bens que acabaram de adquirir, e lealmente espalhando por todo o mundo a soberania da arte francesa. ${ }^{24}$

O termo École de Paris cunhado por Warnod apresentava, assim, uma solução para integrar os artistas estrangeiros numa totalidade cultural cuja sede era a capital francesa. Isso significava que eles eram incluídos nessa "escola" eclética, mas suas potências criativas estavam submetidas a uma instância superior: a metrópole que os acolhia e propiciava suas criações. ${ }^{25} \bigcirc$ texło de Warnod teve grande repercussão, a ponto da expressão se tornar uma categoria 
empregada para abarcar toda a produção artística produzida na Paris modernista, cuja marca era o ecletismo e a diversidade. ${ }^{26}$

Diante desse ambiente que ao mesmo tempo acolhia e hierarquizava os estrangeiros diante daquilo que se entendia por pintura francesa, ${ }^{27}$ quais eram as possibilidades de reconhecimento disponíveis? Consagrar-se na França passava por trilhar alguns caminhos que poderiam se entrecruzar, como pela participação nos salões, pela realização de exposições em galerias e, finalmente, por ter obras adquiridas pelas instituições oficiais, como o Musée du Luxembourg, ou sua versão "estrangeira" recentemente criada, o Musée du Jeu de Paume.

Os salões anuais que então estavam em operação eram cinco: a Société des Artistes Français, fundada em 1881 ; a Société Nationale des Beaux-Arts, inaugurada em 1890; o Salon des Indépendants, surgido em 1884; o Salon d'Automne, funcionando desde 1903; e, finalmente, o Salon des Tuileries, criado em 1923. Com exceção do primeiro, todos os demais aceitavam estrangeiros dentre seus expositores. No entanto, os perfis e prestígios desses salões eram distintos. O Salon de la Nationale, como era conhecido aquele promovido pela Société Nationale des Beaux-Arts, era nitidamente mais conservador, caudatário da tradição da École des Beaux-Arts; ao passo que o Salon d'Automne e o Salon des Indépendants eram os mais abertos às vanguardas. Dentre eles, o primeiro possuía mais prestígio no campo, por possuir um júri e, portanto, ser mais seletivo (instância que o Salon des Indépendants propositalmente refutava) e, também, por ter realizado exposições notórias, como a de 1905, onde estrearam os fauves. $\bigcirc$ Salon des Tuileries despontou apenas em 1923, como uma tentativa de congregar todos os "modernos" num único lugar, procurando ser um espaço de conciliação, isso em uma época em que a crise dos salões já se fazia sentir. ${ }^{28}$

Os salões ofereciam uma oportunidade ímpar para os artistas latinoamericanos participarem do circuito artístico francês. Segundo Michele Greet, cerca de sessenta artistas latino-americanos enviaram obras para os salões no período estudado, alguns deles expondo com regularidade. ${ }^{29}$ Embora poucos tenham conseguido conquistar prêmios e distinções nesses espaços, para muitos foi a oportunidade de terem suas obras vistas e comentadas por críticos. Com efeito, a repercussão na imprensa era fundamental para a carreira, aumentando as chances de serem aceitos por galerias. $\bigcirc$ sucesso nos salões se traduzia também em repercussões importantes em seus países de origem, o que thes possibilitava prestígio quando de seus retornos.

Ao lado dessas instituições, a participação no mercado artístico era importante para se fazer notar. Cada vez mais expor a obra numa galeria se
26. Bertrand Dorléac (1996).

27. Sobre as diferenças matizes e debates do que se entendia então por pintura francesa, ler: GREET (op. cit., p. 64-65). O autor explica que a ideia de uma "Escola francesa" de pintura moderna era defendida por diversos críticos do período mas encontrava variações, comportando desde uma visão claramente organicista de pátria e xenófoba, como a defendida pelo crítico $\mathrm{Ca}$ mille Mauclair, até uma versão aberta à participação dos estrangeiros, com suas particularidades de origem, cultura, religião e estilo, mas na medida em que produziam sob os auspícios de Paris e integravam suas contribuições ao "espírito francês”, posição defendida por André Warnod. No entanto, a posição média e que parece ter contado com mais seguidores foi aquela representada por artistas como Lhote e Bissière e pelo crítico Vauxcelles, para os quais a realidade nacional francesa seria devedora mais de um ideal de comunidade territorial única pela vontade do povo, do que por uma visão organicista de filiação nacional ou pertencimento étnico. Do ponto de vista estético, isso traduziria uma propensão para um realismo caudatário da escola cézaniana, erguida como um paradigma da tradição moderna francesa.

28. Maingon (2014).

29. Greet (2017). 
30. Joyeux-Prunel (2017, p. 67).

31. Greet (2017, p. 129)

32. Sobre as galerias de $\mathrm{Pa}-$ ris ler: Saint-Raymond; Maupeou; Cavero (2016)

33. Cf. Greet (2017). tornava um elemento crucial para alçar visibilidade na Paris modernista. ${ }^{30}$ Alguns críticos cobriam constantemente as exposições dos salões por meio de artigos em periódicos, como fazia Waldemar George em L'Amour de L'art; ou ainda Maurice Raynal em seus textos publicados no L'Intransigeant, e, especialmente, o crítico Raymond Cogniat, que cobria as exposições dos latinoamericanos na Revue de l'Amérique Latine. ${ }^{31}$ Foram eles os intermediários decisivos para a notabilização de alguns artistas latino-americanos.

Durante os anos 1920, como bem demonstram Michele Greet, Claire Maignon e Béatrice Joyeux-Prunel, os salões haviam perdido o monopólio de consagração, enquanto o sistema de galerias crescera de modo vertiginoso, chegando a 130 estabelecimentos em funcionamento nessa década. Cerca de trinta artistas latino-americanos realizaram individuais em galerias de prestígio em Paris, ${ }^{32}$ pouco menos de um décimo dos cerca de 330 artistas que realizaram estadias na cidade nesse período. Esse pequeno número de expositores evidencia a seletividade desse sistema, bem como a dificuldade enfrentada por essa população de estrangeiros para efetivar um passo tão decisivo para alcançar visibilidade e reconhecimento artístico.

Na concorridíssima rue La Boétie, Max Jimenez, Tarsila do Amaral e Joaquín Torres Garcia expuseram obras na Galerie Percier; enquanto na prestigiosa galeria L'Effort Moderne, Vicente do Rego Monteiro, Emilio Pettoruti e Tarsila do Amaral foram exibidos entre os anos 1920 e o começo dos 1930. ${ }^{33}$ Ainda na na Rive Droite, o uruguaio Carlos Castellanos realizou uma individual na Galerie Durand-Ruel em 1927, enquanto seu compatriota, o pintor Pedro Figari, expôs na Galerie Druet em 1923, 1925 e 1927. Uma das telas de Figari expostas em 1927, intitulada Danse créole (Figuras 1 e 2) foi adquirida pelo governo e enviada ao Musée Jeu de Paume, que então abrigava as coleções de arte estrangeira contemporânea. Trata-se da única obra do artista comprada no período entreguerras hoje pertencente ao Musée d'Orsay. Temos aqui um bom exemplo de um processo de consagração que se completou. Mas quantos latino- americanos conseguiram tal feito? 


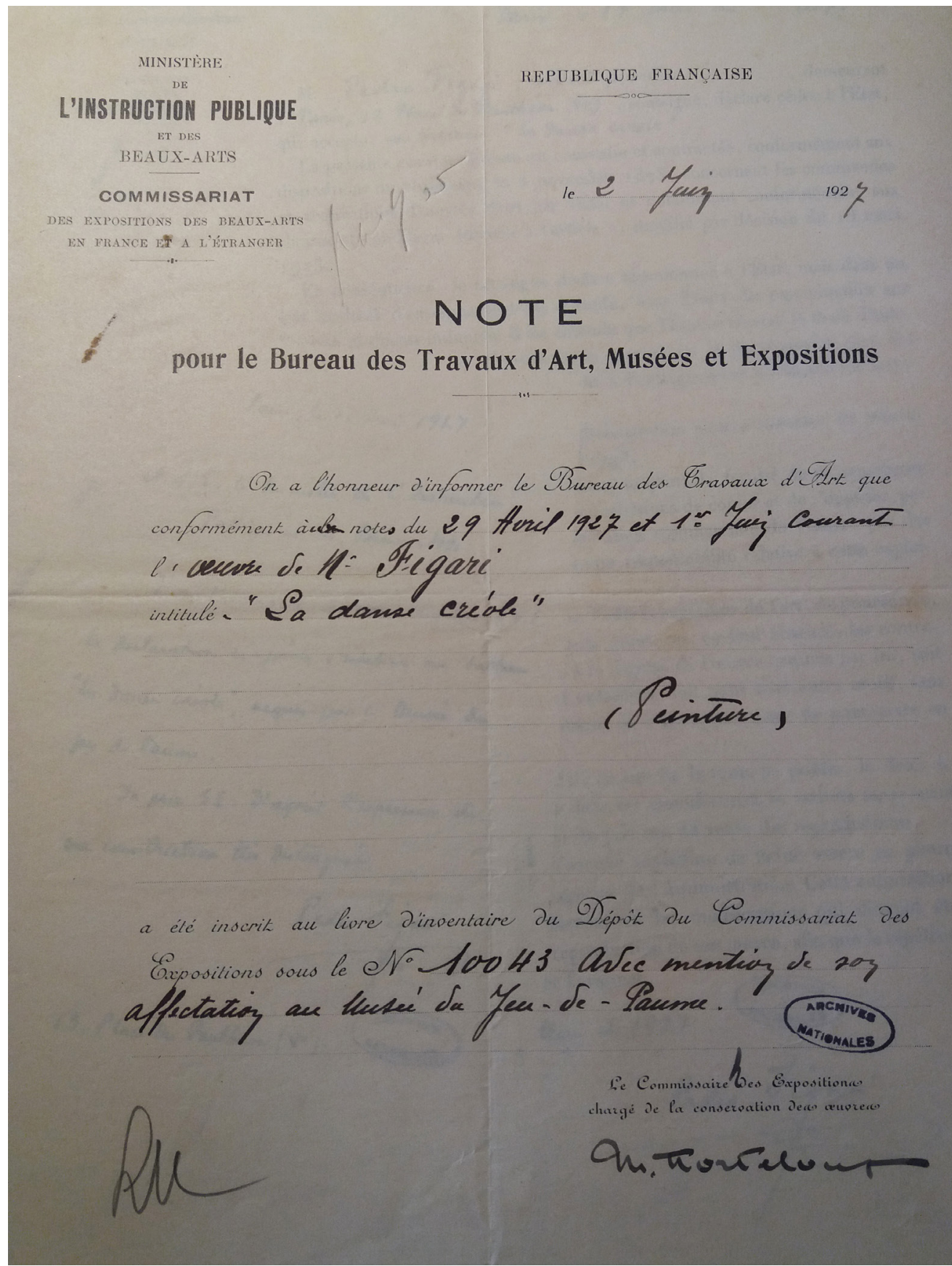

Figura 1 - Recibo de compra da obra La Danse Créole. Pasta de Figari. Archives Nationeles. Pasta F/21/4208. Foto: Autora. 


\section{Pani, 617 thai 1924}

$$
\begin{aligned}
& \text { AS.S. L Mivintis de I'Insirnaction } \\
& \text { Pubtican of des Beause trits. }
\end{aligned}
$$

$$
\text { I' ai l'houncur de remethe a. V.S. }
$$

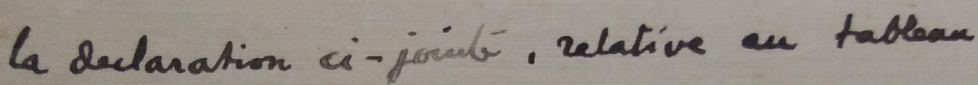

"La dause criobe", aequer var le Mnessé de

ker de Taume.

$$
\text { Ya pie SE. J'agriear L'erpeancion de }
$$

ma conichration tisi ritünqué

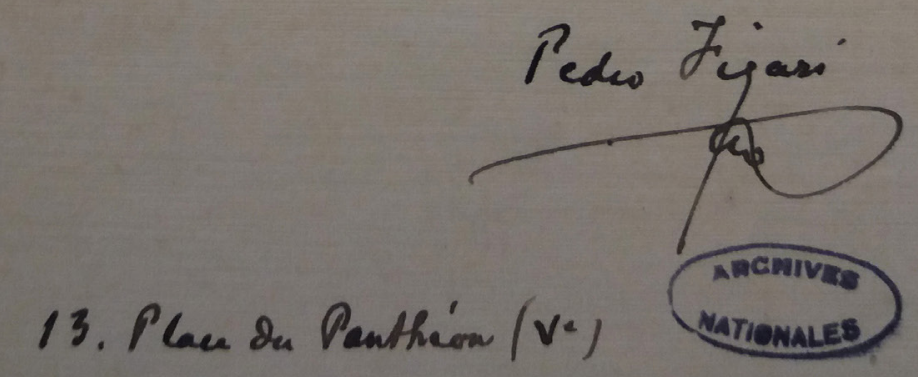

Figura 2 - Manuscrito assinado por Pedro Figari declarando envio da tela adquirida para o Musée du Jeu de Paume. Archives Nationeles. Pasta F/21/4208. Archives Nationales. Foto: Autora. 


\section{A PRESENÇA DOS ARTISTAS LATINO-AMERICANOS NAS COLEÇÕES PÚBLICAS FRANCESAS}

A partir de levantamentos feitos em diversas bases e fontes, chegou-se à cifra de 333 artistas latino-americanos atuantes na Paris modernista. ${ }^{34}$ Dentre esses, apenas 23 homens e cinco mulheres conseguiram ter ao menos uma de suas obras incluídas em uma coleção pública francesa. Isso significa que 305 artistas não obtiveram esse grau de consagração, ou seja, a imensa maioria (91,5\%). A cifra de êxito, neste âmbito, é ainda inferior aos $9,0 \%$ de artistas que puderam expor em galerias privadas, uma vez que o índice de musealização alcançaria modestos $8.5 \%$.

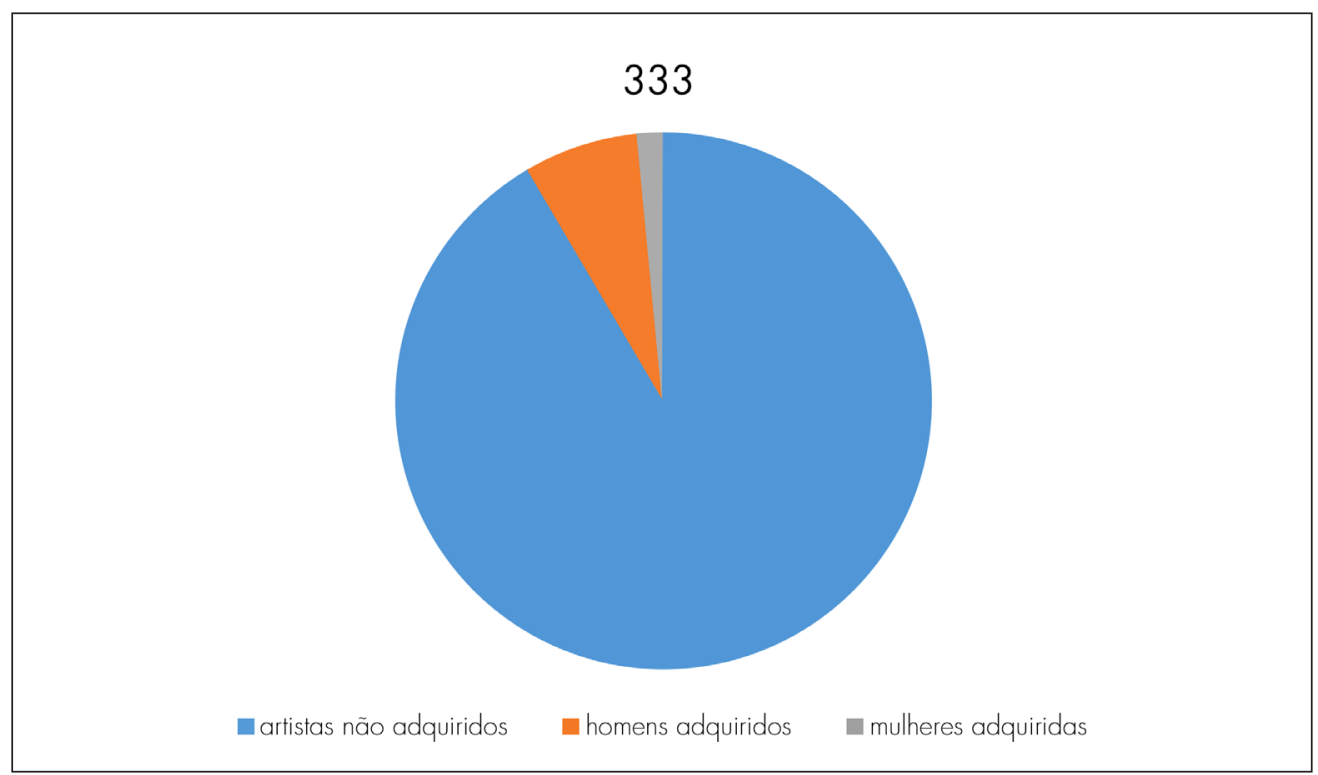

Figura 3 - Gráfico referente à aquisição de obras de artistas latino-americanos pelos museus franceses.

Frise-se que o levantamento indica que a quantidade de obras femininas musealizadas é discretamente menor que as produzidas por homens. Em termos absolutos, apenas cinco artistas foram retidas pelas instituições las brasileiras Anita Malfatti e Tarsila do Amaral; a peruana Carmen Sacco; a mexicana Frida Kahlo e a venezuelana Emile Boggio). Mas é preciso nuançar esse dado, pois a quantidade de mulheres artistas latino-americanas em Paris no período era, também, consideravelmente inferior à masculina. Dentre os 333 artistas atuantes na cidade, 263 eram do sexo masculino, sendo que 23 deles tiveram obras musealizadas $(8,7 \%)$, ao passo que $240(91,3 \%)$ não. No mesmo período, cerca de setenta mulheres artistas estiveram em Paris, e apenas cinco delas obtiveram obras ingressando em museus $(7,1 \%)$, enquanto $65(92,9 \%)$ não lograram tal feito.
34. Utilizei as seguintes bases, na França, Arcade CNAP, Réunion des Musées Nationaux e Joconde, e, ain$\mathrm{da}$, consulta presencial às pastas dos artistas e aquisições disponibilizadas pelos Archives Nationales. O site Transatlantic Encounters, construído por Michele Greet, foi usado como grade comparativa. Para o número preciso de 333 , exclui casos duvidosos ou que comportavam erros. Optei, não sem dilemas, em excluir artistas que atuaram muito no Brasil e tiveram suas obras adquiridas na França, tais como Lasar Segall e Samson Flexor. Embora os considere fundamentais para o desenvolvimento da "arte no Brasil”. Mas a exclusão se deve ao escopo aqui abordado. Eu não teria como ombrear casos como os deles a outros artistas estrangeiros que tiveram papéis equivalentes em outros países, como México, Argentina, Peru, Chile etc. Por isso, acabei optando por uma visão restritiva calcada na origem ou nacionalidade, que é o que as bases me fornecem de modo mais objetivo e estável. A cifra de 333 é a mais fidedigna possível, mas pode sofrer relativas mudanças com novas pesquisas futuras. 
35. Carta de Anita Malfatti a Mário de Andrade. Paris, c. meados de novembro de 1926. Arquivo do Instituto de Estudos Brasileiros da Universidade de São Paulo.
Tais dados quantitativos podem ser contrapostos a narrativas habituais da história da arte, traçadas a partir de casos individuais de artistas que, de algum modo, perfizeram estadias "bem-sucedidas" em Paris. Quantos textos de época ou mesmo trabalhos acadêmicos celebraram o "sucesso" de Tarsila em Paris, coroado por sua exposição na Galerie Percier, independentemente de se saber se as obras foram realmente vendidas ou não? Ou ainda o caso de Anita Malfatti, que em missiva trocada com Mário de Andrade, seu amigo pessoal e crítico afamado em São Paulo, comentava feliz a compra de uma de suas pinturas pelo Estado francês. Dizia ela:

Por aqui altas novidades. Mandei a tal tela de que já falei a você para o Salon du Franc. Houve o célebre leilão apuraram com 147 telas, quase 800.000 francos. Minha tela foi rematada pelo "Etat", de modo que ficará para algum museu da França. Que tal heim? Era o meu desejo.

Pensei no princípio que fosse algum comprador particular, mas depois é que soube a boa notícia. Sempre fica bem ter uma tela comprada pelo governo da França. Pode dar-me um vasto abraço. Acho que mereço. Contei a você que por causa desta tela o Fujita pediu uma apresentação? "Ça commence à gazer" como diz o parisiense [... . ${ }^{35}$

No entanto, como se verá, essa tela jamais foi exposta e até hoje seu paradeiro é desconhecido. Esses sucessos episódicos tenderam a ser muito valorizados pelos próprios artistas e ecoaram positivamente em seus países de origem. Mas uma perspectiva ampliada permite perceber que, de modo geral, a maioria dos artistas latino-americanos não se notabilizou em Paris. Considerando-se o critério da musealização das obras como o ponto final do processo de consagração, isso se torna bastante evidente. Como se mostrou, o índice de musealização foi inferior a 10\% dos artistas, entre homens e mulheres.

Deve-se ainda ressaltar que, no entreguerras, as obras foram adquiridas por compra ou por doação, realizada pelo próprio artista, por colecionadores ou por familiares, postumamente. Essas modalidades possuem hierarquias de prestígio distintas, sendo a aquisição por compra a modalidade mais respeitável, posto que consiste em uma escolha realizada por um conjunto de especialistas, cuja autoridade foi legitimada pelo Estado e por suas instituições culturais. Apesar das falhas documentais nos processos de aquisição arquivados, no caso do contingente de artistas latino-americanos aqui estudado pode-se chegar ao seguinte quadro: 


\begin{tabular}{|c|c|c|c|c|c|}
\hline $\begin{array}{l}\text { Nome do } \\
\text { artista }\end{array}$ & Origem & $\begin{array}{l}\text { Obras adqui- } \\
\text { ridas/Ano } \\
\text { de aquisição } \\
\text { da obra }\end{array}$ & $\begin{array}{l}\text { Modalidade } \\
\text { de transação }\end{array}$ & Proveniência & Destino \\
\hline $\begin{array}{l}\text { Acuña, Luis } \\
\text { Alberto }\end{array}$ & Colômbia & $\begin{array}{l}\text { Nessus sédui- } \\
\text { sant Déjanire/ } \\
1926\end{array}$ & Compra & $\begin{array}{l}\text { Proveniente } \\
\text { do Salon du } \\
\text { Franc }\end{array}$ & $\begin{array}{l}\text { Localização } \\
\text { desconhecida }\end{array}$ \\
\hline $\begin{array}{l}\text { Barreda, } \\
\text { Enrique }\end{array}$ & Peru & $\begin{array}{l}\text { Saint-Jean-de- } \\
\text {-Luz, le port/ } \\
1928\end{array}$ & Compra & $\begin{array}{l}\text { Galerie Char- } \\
\text { pentier }\end{array}$ & $\begin{array}{l}\text { Musée du Jeu } \\
\text { de Paume. } \\
\text { Transferido } \\
\text { para Musée } \\
\text { des Beaux-Arts } \\
\text { Meurthe-et- } \\
\text { Moselle }\end{array}$ \\
\hline $\begin{array}{l}\text { Beltran-Mas- } \\
\text { ses, F. }{ }^{36}\end{array}$ & $\begin{array}{l}\text { Cuba/Espa- } \\
\text { nha }\end{array}$ & $\begin{array}{l}\text { La Duchesse } \\
\text { Sforza; } \\
\text { Pierrot Mala- } \\
\text { de (adquirida } \\
\text { em 1933); } \\
\text { L'Offrande } \\
\text { Portrait du } \\
\text { navigateur } \\
\text { Alain Gerbault } \\
\text { (todas sem } \\
\text { informação de } \\
\text { ano) }\end{array}$ & $\begin{array}{l}\text { Sem informa- } \\
\text { ção }\end{array}$ & $\begin{array}{l}\text { Sem informa- } \\
\text { ção }\end{array}$ & $\begin{array}{l}\text { Réunion des } \\
\text { Musées Natio- } \\
\text { naux }\end{array}$ \\
\hline $\begin{array}{l}\text { Brecheret, } \\
\text { Victor }\end{array}$ & Brasil & $\begin{array}{l}\text { Bélier; } \\
\text { Amazonas ou } \\
\text { Le Groupe/ } \\
1934\end{array}$ & $\begin{array}{l}\text { Doação do } \\
\text { artista }\end{array}$ & $\begin{array}{l}\text { Doação do } \\
\text { artista }\end{array}$ & $\begin{array}{l}\text { Musée Jeu de } \\
\text { Paume. Em } \\
\text { depósito à } \\
\text { Mairie de La } \\
\text { Roche-sur-Yon } \\
\text { depois de } \\
1954\end{array}$ \\
\hline $\begin{array}{l}\text { Carreño, } \\
\text { Mario }\end{array}$ & Cuba/Chile & $\begin{array}{l}\text { Sem informa- } \\
\text { ção/1939 }\end{array}$ & Compra & $\begin{array}{l}\text { Galerie } \\
\text { Bernheim- } \\
\text {-Jeune }\end{array}$ & $\begin{array}{l}\text { Não consta } \\
\text { na base } \\
\text { Arcade. Sem } \\
\text { informação } \\
\text { do nome e } \\
\text { paradeiro da } \\
\text { obra }\end{array}$ \\
\hline
\end{tabular}

36. Na base Arcade não há uma única menção a obras desse artista em coleções públicas, mas no site do Musée Pompidou/Réunion des Musées Nationaux há outras informações. 


\begin{tabular}{|c|c|c|c|c|c|}
\hline $\begin{array}{l}\text { Nome do } \\
\text { artista }\end{array}$ & Origem & $\begin{array}{l}\text { Obras adqui- } \\
\text { ridas/Ano } \\
\text { de aquisição } \\
\text { da obra }\end{array}$ & $\begin{array}{l}\text { Modalidade } \\
\text { de transação }\end{array}$ & Proveniência & Destino \\
\hline \multirow[t]{2}{*}{$\begin{array}{l}\text { Castellanos, } \\
\text { Carlos }\end{array}$} & \multirow[t]{2}{*}{ Uruguai } & $\begin{array}{l}\text { La porteuse } \\
\text { d'eau/1919 } \\
\text { Les chasseurs } \\
\text { (sud amérique } \\
\text { tropicall/ } \\
1919 \\
\text { Marchands } \\
\text { d'oiseaux/ } \\
1919\end{array}$ & Compra & $\begin{array}{l}\text { Salon } \\
\text { d'Automne }\end{array}$ & $\begin{array}{l}\text { Musée du } \\
\text { Luxembourg }\end{array}$ \\
\hline & & $\begin{array}{l}\text { Espagnols } \\
\text { surpris par des } \\
\text { Indiens/1926 }\end{array}$ & $\begin{array}{l}\text { Sem informa- } \\
\text { ção }\end{array}$ & $\begin{array}{l}\text { Salon du } \\
\text { Franc }\end{array}$ & $\begin{array}{l}\text { Paradeiro des } \\
\text { conhecido. } \\
\text { Dossiê vazio } \\
\end{array}$ \\
\hline $\begin{array}{l}\text { Coria, Benja- } \\
\text { min }\end{array}$ & México & $\begin{array}{l}\text { Nature mor- } \\
\text { te/1926 }\end{array}$ & $\begin{array}{l}\text { Sem informa- } \\
\text { ção }\end{array}$ & $\begin{array}{l}\text { Salon du } \\
\text { Franc }\end{array}$ & $\begin{array}{l}\text { Sem informa- } \\
\text { ção. Atribuído } \\
\text { à Mairie de } \\
\text { Vitry-sur-Loire } \\
\text { en } 1937\end{array}$ \\
\hline $\begin{array}{l}\text { Cardenas } \\
\text { Castro, Juan } \\
\text { Manuel }\end{array}$ & Peru & $\begin{array}{l}\text { Imprecion } \\
{[\text { sic! }] / 1926}\end{array}$ & $\begin{array}{l}\text { Sem informa- } \\
\text { ção }\end{array}$ & $\begin{array}{l}\text { Salon du } \\
\text { Franc }\end{array}$ & $\begin{array}{l}\text { Sem informa- } \\
\text { ção. Dossiê } \\
\text { vazio }\end{array}$ \\
\hline $\begin{array}{l}\text { Di Cavalcanti, } \\
\text { Emiliano }\end{array}$ & Brasil & $\begin{array}{l}\text { Scène brési- } \\
\text { lienne/1939 }\end{array}$ & Compra & $\begin{array}{l}\text { Galeria } \\
\text { Billiers- Wor- } \\
\text { ms }\end{array}$ & $\begin{array}{l}\text { Museu do Jeu } \\
\text { de Paume }\end{array}$ \\
\hline Figari, Pedro & Uruguai & $\begin{array}{l}\text { La danse créo- } \\
\text { le/1927 }\end{array}$ & Compra & $\begin{array}{l}\text { Sem informa- } \\
\text { ção }\end{array}$ & $\begin{array}{l}\text { Musée du Jeu } \\
\text { de Paume }\end{array}$ \\
\hline \multirow{3}{*}{$\begin{array}{l}\text { Fonseca, } \\
\text { Gaston de }\end{array}$} & \multirow{3}{*}{ Brasil } & $\begin{array}{l}\text { La fontaine } \\
\text { de Castalie } \\
\text { à Delphes/ } \\
1923\end{array}$ & Compra & $\begin{array}{l}\text { Sem informa- } \\
\text { ção }\end{array}$ & $\begin{array}{l}\text { Sem informa- } \\
\text { ção }\end{array}$ \\
\hline & & $\begin{array}{l}\text { Tela sem infor- } \\
\text { mação/1933 } \\
\end{array}$ & Compra & $\begin{array}{l}\text { Sem informa- } \\
\text { ção }\end{array}$ & $\begin{array}{l}\text { Sem informa- } \\
\text { ção }\end{array}$ \\
\hline & & $\begin{array}{l}\text { Femme à la } \\
\text { guitare/ } 1936\end{array}$ & Compra & $\begin{array}{l}\text { Sem informa- } \\
\text { ção }\end{array}$ & - \\
\hline Lagos, Alberto & Argentina & $\begin{array}{l}\text { Douleureuse/ } \\
1924\end{array}$ & Compra & $\begin{array}{l}\text { Sem informa- } \\
\text { ção }\end{array}$ & $\begin{array}{l}\text { Musée du } \\
\text { Luxembourg }\end{array}$ \\
\hline
\end{tabular}




\begin{tabular}{|c|c|c|c|c|c|}
\hline $\begin{array}{l}\text { Nome do } \\
\text { artista }\end{array}$ & Origem & $\begin{array}{l}\text { Obras adqui- } \\
\text { ridas/Ano } \\
\text { de aquisição } \\
\text { da obra }\end{array}$ & $\begin{array}{l}\text { Modalidade } \\
\text { de transação }\end{array}$ & Proveniência & Destino \\
\hline \multirow{3}{*}{$\begin{array}{l}\text { Zarate Orhtis, } \\
\text { Miguel }\end{array}$} & \multirow{3}{*}{ Chile } & $\begin{array}{l}\text { Natureza } \\
\text { morta/1926 }\end{array}$ & Compra & $\begin{array}{l}\text { Sem informa- } \\
\text { ção }\end{array}$ & $\begin{array}{l}\text { Sem informa- } \\
\text { ção }\end{array}$ \\
\hline & & Fleurs/1929 & Compra & $\begin{array}{l}\text { Sem informa- } \\
\text { ção }\end{array}$ & $\begin{array}{l}\text { Musée du } \\
\text { Luxembourg }\end{array}$ \\
\hline & & $\begin{array}{l}\text { Dom Quixote } \\
\text { de la man- } \\
\text { cha/1937 }\end{array}$ & Compra & $\begin{array}{l}\text { Sem informa- } \\
\text { ção }\end{array}$ & Marie de Tarn \\
\hline \multirow{2}{*}{$\begin{array}{l}\text { Rego Mon- } \\
\text { teiro, Vicente } \\
\text { do }^{37}\end{array}$} & \multirow{2}{*}{ Brasil } & $\begin{array}{l}\text { Les Boxeurs/ } \\
1928\end{array}$ & Compra & $\begin{array}{l}\text { Galeria } \\
\text { Berhaim-Jeune } \\
\end{array}$ & $\begin{array}{l}\text { Musée de } \\
\text { Grenoble }\end{array}$ \\
\hline & & $\begin{array}{l}\text { L'Enfant/ } \\
1937\end{array}$ & Compra & - & $\begin{array}{l}\text { Musée du Jeu } \\
\text { de Paume }\end{array}$ \\
\hline $\begin{array}{l}\text { Rendon, } \\
\text { Manuel }\end{array}$ & Equador & $\begin{array}{l}\text { Femmes } \\
\text { Nues/1926 }\end{array}$ & $\begin{array}{l}\text { Sem informa- } \\
\text { ção }\end{array}$ & $\begin{array}{l}\text { Salon du } \\
\text { Franc }\end{array}$ & $\begin{array}{l}\text { Musée de } \\
\text { Grenoble. } \\
\text { Dossiê vazio }\end{array}$ \\
\hline \multirow[t]{2}{*}{ Rozo, Rómulo } & \multirow[t]{2}{*}{ Colômbia } & Fauno/1928 & Compra & $\begin{array}{l}\text { Exposição } \\
\text { Cercle de } \\
\text { l'Amerique } \\
\text { Latine }\end{array}$ & $\begin{array}{l}\text { Sem informa- } \\
\text { ção }\end{array}$ \\
\hline & & $\begin{array}{l}\text { Sem informa- } \\
\text { ção/1926 }\end{array}$ & $\begin{array}{l}\text { Sem informa- } \\
\text { ção }\end{array}$ & $\begin{array}{l}\text { Salon du } \\
\text { Franc }\end{array}$ & Dossiê vazio \\
\hline $\begin{array}{l}\text { Sangroniz, } \\
\text { Luis Alberto de }\end{array}$ & Chile & $\begin{array}{l}\text { Sem informa- } \\
\text { ção/1924 }\end{array}$ & Compra & $\begin{array}{l}\text { Sem informa- } \\
\text { ção }\end{array}$ & $\begin{array}{l}\text { Sem informa- } \\
\text { ção }\end{array}$ \\
\hline $\begin{array}{l}\text { Sicre, Juan } \\
\text { José }\end{array}$ & Cuba & $\begin{array}{l}\text { Femme } \\
\text { agenouillée/ } \\
1926\end{array}$ & $\begin{array}{l}\text { Sem informa- } \\
\text { ção precisa }\end{array}$ & $\begin{array}{l}\text { Salon du } \\
\text { Franc }\end{array}$ & $\begin{array}{l}\text { Transferido pa- } \\
\text { ra a Nouvelle- } \\
\text {-Calédonie } \\
\text { em } 1930\end{array}$ \\
\hline \multirow[b]{2}{*}{$\begin{array}{l}\text { Terry, José } \\
\text { Antonio }\end{array}$} & \multirow[b]{2}{*}{ Argentina } & $\begin{array}{l}\text { La naine che- } \\
\text { pa avec sa } \\
\text { cruche/1924 }\end{array}$ & Compra & $\begin{array}{l}\text { Galerie Char- } \\
\text { pentier }\end{array}$ & $\begin{array}{l}\text { Musée du } \\
\text { Luxembourg }\end{array}$ \\
\hline & & $\begin{array}{l}\text { Colonne } \\
\text { en marbre } \\
\text { surmontée } \\
\text { d'une urne } \\
\text { en marbre et } \\
\text { granit/1937 }\end{array}$ & Compra & $\begin{array}{l}\text { Obra enco- } \\
\text { mendada } \\
\text { e doada à } \\
\text { Cidade de } \\
\text { Evian }\end{array}$ & $\begin{array}{l}\text { Mairie } \\
\text { d'Evian-les- } \\
\text {-Bains }\end{array}$ \\
\hline $\begin{array}{l}\text { Toledo Piza, } \\
\text { Domingos V. }\end{array}$ & Brasil & $\begin{array}{l}\text { Paysage de } \\
\text { neige/1934 }\end{array}$ & Compra & $\begin{array}{l}\text { Sem informa- } \\
\text { ção }\end{array}$ & $\begin{array}{l}\text { Musée du Jeu } \\
\text { de Paume }\end{array}$ \\
\hline $\begin{array}{l}\text { Quinquela } \\
\text { Martín, Benito }\end{array}$ & Argentina & $\begin{array}{l}\text { Effet d'orage/ } \\
1926\end{array}$ & Compra & $\begin{array}{l}\text { Galerie Char- } \\
\text { pentier }\end{array}$ & $\begin{array}{l}\text { Musée du Jeu } \\
\text { de Paume }\end{array}$ \\
\hline
\end{tabular}

37. Além das telas citadas, Vicente do Rego Monteiro teve outras telas adquiridas posteriormente pelo governo francês, após o marco temporal da presente pesquisa, são elas: L'Adoration des Bergers, em 1953, La chasse, em 1959, Le Buveur, em 1964. 
38. Emilie Boggio (18571920), artista de origem venezuelana, teve três obras adquiridas pelo Estado francês antes do período estudado nesta pesquisa. Não é uma artista de orientação modernista. Cf. <https://bit.ly/3eJ1aOt>.

39. Em suas memórias, Anita Malfatti afirmou que a obra foi comprada pelo Estado. Porém, em seu dossiê nos Archives Nationales CONSTA "Transação desconhecida" e o dossiê, tal como outros provenientes do Salon du Franc, está vazio.

\begin{tabular}{|c|c|c|c|c|c|}
\hline $\begin{array}{l}\text { Nome do } \\
\text { artista }\end{array}$ & Origem & $\begin{array}{l}\text { Obras adqui- } \\
\text { ridas/Ano } \\
\text { de aquisição } \\
\text { da obra }\end{array}$ & $\begin{array}{l}\text { Modalidade } \\
\text { de transação }\end{array}$ & Proveniência & Destino \\
\hline \multirow{2}{*}{$\begin{array}{l}\text { Valenzuela } \\
\text { Llanos, Alberto }\end{array}$} & \multirow{2}{*}{ Chile } & $\begin{array}{l}\text { Sem título/ } \\
1913\end{array}$ & Compra & $\begin{array}{l}\text { Sem informa- } \\
\text { ção }\end{array}$ & $\begin{array}{l}\text { Sem informa- } \\
\text { ção }\end{array}$ \\
\hline & & $\begin{array}{l}\text { Arbrisseaux en } \\
\text { fleurs/1924 }\end{array}$ & Compra & $\begin{array}{l}\text { Galerie Geor- } \\
\text { ges Petit }\end{array}$ & $\begin{array}{l}\text { Musée du } \\
\text { Luxembourg }\end{array}$ \\
\hline \multirow{7}{*}{$\begin{array}{l}\text { Zárraga, } \\
\text { Ángel }\end{array}$} & \multirow{7}{*}{ México } & Angel/1926 & $\begin{array}{l}\text { Sem informa- } \\
\text { ção }\end{array}$ & $\begin{array}{l}\text { Salon du } \\
\text { Franc }\end{array}$ & $\begin{array}{l}\text { Musée du Jeu } \\
\text { de Paume }\end{array}$ \\
\hline & & $\begin{array}{l}\text { Nu [Etude } \\
\text { pour une } \\
\text { architecture } \\
\text { de Auguste } \\
\text { Perret]/1937 }\end{array}$ & Compra & $\begin{array}{l}\text { Sem informa- } \\
\text { ção }\end{array}$ & $\begin{array}{l}\text { Atribuição do } \\
\text { Estado- RMN }\end{array}$ \\
\hline & & $\begin{array}{l}\text { La partie de } \\
\text { football/ } \\
1926\end{array}$ & $\begin{array}{l}\text { Doação do } \\
\text { artista ao } \\
\text { Estado }\end{array}$ & $\begin{array}{l}\text { Sem informa- } \\
\text { ção }\end{array}$ & RMN \\
\hline & & $\begin{array}{l}\text { Portrait de } \\
\text { Mme Zarra- } \\
\text { ga/ } 1924\end{array}$ & $\begin{array}{l}\text { Doação de } \\
\text { René Philipon }\end{array}$ & $\begin{array}{l}\text { Coleção René } \\
\text { Philipon }\end{array}$ & RMN \\
\hline & & $\begin{array}{l}\text { Portrait de } \\
\text { Pierre Bon- } \\
\text { nard/1924 }\end{array}$ & $\begin{array}{l}\text { Doação de } \\
\text { René Philipon }\end{array}$ & $\begin{array}{l}\text { Coleção René } \\
\text { Philipon }\end{array}$ & RMN \\
\hline & & $\begin{array}{l}\text { La baignade/ } \\
1925\end{array}$ & $\begin{array}{l}\text { Doação René } \\
\text { Philipon }\end{array}$ & $\begin{array}{l}\text { Coleção René } \\
\text { Philipon }\end{array}$ & RMN \\
\hline & & $\begin{array}{l}\text { Portrait de M. } \\
\text { Philipon }\end{array}$ & $\begin{array}{l}\text { Doação René } \\
\text { Philipon }\end{array}$ & $\begin{array}{l}\text { Coleção René } \\
\text { Philipon }\end{array}$ & RMN \\
\hline $\begin{array}{l}\text { MULHERES } \\
\text { ARTISTAS }\end{array}$ & Origem & $\begin{array}{l}\text { Obras/Data } \\
\text { de aquisição }\end{array}$ & Modalidade & Proveniência & Destino \\
\hline $\begin{array}{l}\text { Amaral, Tarsi- } \\
\text { la do }\end{array}$ & Brasil & $\begin{array}{l}\text { Compo- } \\
\text { sition [A } \\
\text { cuca]/1926 }\end{array}$ & $\begin{array}{l}\text { Doação da } \\
\text { artista }\end{array}$ & $\begin{array}{l}\text { Salon du } \\
\text { Franc }\end{array}$ & $\begin{array}{l}\text { Musée de } \\
\text { Grenoble }\end{array}$ \\
\hline $\begin{array}{l}\text { Boggio, } \\
\text { Emile }^{38}\end{array}$ & Venezuela & $\begin{array}{l}\text { Un prunier de } \\
\text { mon jardin au } \\
\text { soleil/1919 }\end{array}$ & Compra & $\begin{array}{l}\text { Sem informa- } \\
\text { ção }\end{array}$ & $\begin{array}{l}\text { Musée du } \\
\text { Luxembourg }\end{array}$ \\
\hline Kahlo, Frida & México & $\begin{array}{l}\text { Portrait de } \\
\text { l'artiste/1939 }\end{array}$ & Compra & $\begin{array}{l}\text { Galerie Renou } \\
\text { et Colle }\end{array}$ & $\begin{array}{l}\text { Musée du Jeu } \\
\text { de Paume }\end{array}$ \\
\hline Malfatti, Anita & Brasil & Figura/ 1926 & $\begin{array}{l}\text { Sem informa- } \\
\text { ção }\end{array}$ & $\begin{array}{l}\text { Salon du } \\
\text { Franc }\end{array}$ & $\begin{array}{l}\text { Obra não } \\
\text { localizada/ } \\
\text { perdida }^{39}\end{array}$ \\
\hline
\end{tabular}




\begin{tabular}{|l|l|l|l|l|l|}
\hline $\begin{array}{l}\text { MULHERES } \\
\text { ARTISTAS }\end{array}$ & Origem & $\begin{array}{l}\text { Obras/Data } \\
\text { de aquisição }\end{array}$ & Modalidade & Proveniência & Destino \\
\hline $\begin{array}{l}\text { Sacco, Car- } \\
\text { mem }\end{array}$ & Peru & $\begin{array}{l}\text { Sirène dans } \\
\text { un bal mas- } \\
\text { qué/1926 }\end{array}$ & $\begin{array}{l}\text { Sem informa- } \\
\text { ção }\end{array}$ & $\begin{array}{l}\text { Salon du } \\
\text { Franc }\end{array}$ & $\begin{array}{l}\text { Em } 1930 \\
\text { a obra é } \\
\text { transferida } \\
\text { para a Marie } \\
\text { de Nouméa, } \\
\text { Nouvelle } \\
\text { Calédonie }\end{array}$ \\
\hline
\end{tabular}

Tabela 1 - Artistas cujas obras foram musealizadas na França, c. 1910-1947

Ainda que cada um desses processos possua sua história própria e possa ser analisado em sua especificidade, há elementos que se repetem. Em primeiro lugar, em termos de modalidades de aquisição, embora em vários casos as transações sejam desconhecidas, as compras são mais regulares que as doações dos artistas ou de colecionadores. ${ }^{40}$ Em termos de proveniência, há uma reiterada menção ao pouco conhecido Salon du Franc, dado esse que levou a uma pesquisa mais pontual sobre ele, que será abordado a seguir. De acordo com a quantificação, em segundo lugar encontram-se as obras que foram notadas em exposições realizadas em galerias. Apenas em um caso, o das três pinturas de Carlos Castellanos adquiridas em 1919, o Salon d'Automne foi apontado como espaço de proveniência.

Já no que diz respeito ao destino dado às obras adquiridas, a maior parte foi designada ao Musée du Jeu de Paume, que constituía um braço do Musée du Luxembourg dedicado à arte contemporânea estrangeira até 1930, quando se tornou independente. Algumas foram endereçadas ao Musée de Grenoble, que teve um papel pioneiro no colecionismo público de arte moderna para a França, desde os anos 1920, sob a direção renovadora de Andry-Farcy. ${ }^{41}$ Já em 1928, - Musée de Grenoble adquiriu uma tela de Vicente do Rego Monteiro, Les Boxeurs, datada de 1927. No mesmo ano ingressaram ainda duas pinturas, por meio de designação do Estado, a tela Cuca, doada por Tarsila do Amaral Ver Tabela 1), e a pintura Femme nue do equatoriano Manuel Rendon, ambas exibidas no já mencionado Salon du Franc.

Vale lembrar que outras obras foram enviadas para destinos periféricos, para decoração de embaixadas e consulados franceses, em instituições no ultramar colonial (como a Nova Caledônia) ou sedes de prefeituras na própria França (tal como a obra de Benjamin Coria, encaminhada à mairie de Vitry-
40. Na realidade, no período estudado apenas Ángel Zárraga teve obras doadas por colecionadores. No período posterior a 1947 essas doações foram muito mais regulares, como mostra o caso de Joaquim Torres Garcia, que não tem nenhuma obra adquirida neste momento, mas a partir da década de 1950 recebe aquisições e doações diversas para museus franceses.

41. O Musée de Grenoble, sob a direção de Andry-Farcy (1919-1949) exerceu um papel pioneiro na França no que diz respeito à aquisição, musealização e consagração da arte moderna. Foi a primeira instituição a ter obras de Picasso, Modigliani, Chana Orloff, entre outros, em sua coleção e a expô-las ao público já nos anos 1920. Diversas telas e esculturas de artistas estrangeiros foram adquiridas, desde os já citados, até nomes como o do artista bielorusso Ossip Zadkine. Sobre o museu ler: Le Musée de Grenoble (1982). 
42. Cf. $<$ https://bit.ly/3r2x$\mathrm{v} 5 \mathrm{v}>$
sur-Loire), destinações essas que não contribuíram para sua visibilidade e para o amplo reconhecimento dos artistas. Tal opacidade revela-se mesmo no presente, pois essas obras, em geral, não estão reproduzidas nas bases virtuais francesas de obras de arte musealizadas. Nesse cenário pouco consagrador, - caso do Musée de Grenoble é particularmente relevante para os artistas latino-americanos, pois ele foi, até a criação do MNAM, uma instituição referencial para a arte moderna na França.

No que diz respeito às mulheres, entre as cinco mencionadas na Tabela 1, das quais quatro são de orientação modernista, três tiveram obras musealizadas a partir de sua exibição no Salon du Franc, o que sublinha a importância desse evento ocorrido em 1926 para os artistas latino-americanos. É preciso notar que a pesquisa sobre mulheres encontra um desafio maior junto às bases de dados dos Archives Nationales. Embora exista uma rubrica especialmente dedicada aos "noms d'artistes femmes" (artistas mulheres), ${ }^{42}$ apenas Tarsila do Amaral foi encontrada nessa classificação específica. As demais artistas estão na listagem geral, dedicada aos "nom d'artist" (nome de artistas, podendo ser confundidas com homens). Provavelmente isso se deve à barreira linguística e à dificuldade de identificação dos nomes próprios femininos em outro idioma. Anita Malfatti e Carmen Sacco aparecem na lista de artistas gerais e estão introduzidas por M., abreviatura de monsieur, ou seja, senhor. $\bigcirc$ caso de Frida Kahlo merece ainda comentários particulares, pois aparece listada como "mme. Kahlo" de Rivera e, portanto, na lista R, como "Rivera", ainda que precedida com "mme.", ou seja, senhora. No dossiê, a situação é ainda mais problemática, pois é mencionada como Frida de Rivera.

Até onde se sabe, Frida jamais assinou seu nome como "senhora Kahlo Rivera", mas esse deslize é compreensível quando se lê o parecer que embasou a compra da tela. O texto assinado por André Dezarrois, conservador responsável pelo Musée du Jeu de Paume:

A esposa do mais importante pintor vivo das duas Américas, Diego Rivera, ela mesma uma artista curiosa e talentosa, acaba de realizar uma exposição em Paris, na Galeria Renou et Colle, sob o patrocínio do poeta André Breton, obras de caráter surrealista, algumas das quais charmosas, especialmente um autorretrato; antes de regressar ela propôs que a deixaria para as coleções do Jeu de Paume onde a arte mexicana é, por assim dizer, inexistente, por uma soma de 1.000 francos. Tenho assim a honra de the propor essa aquisição. 


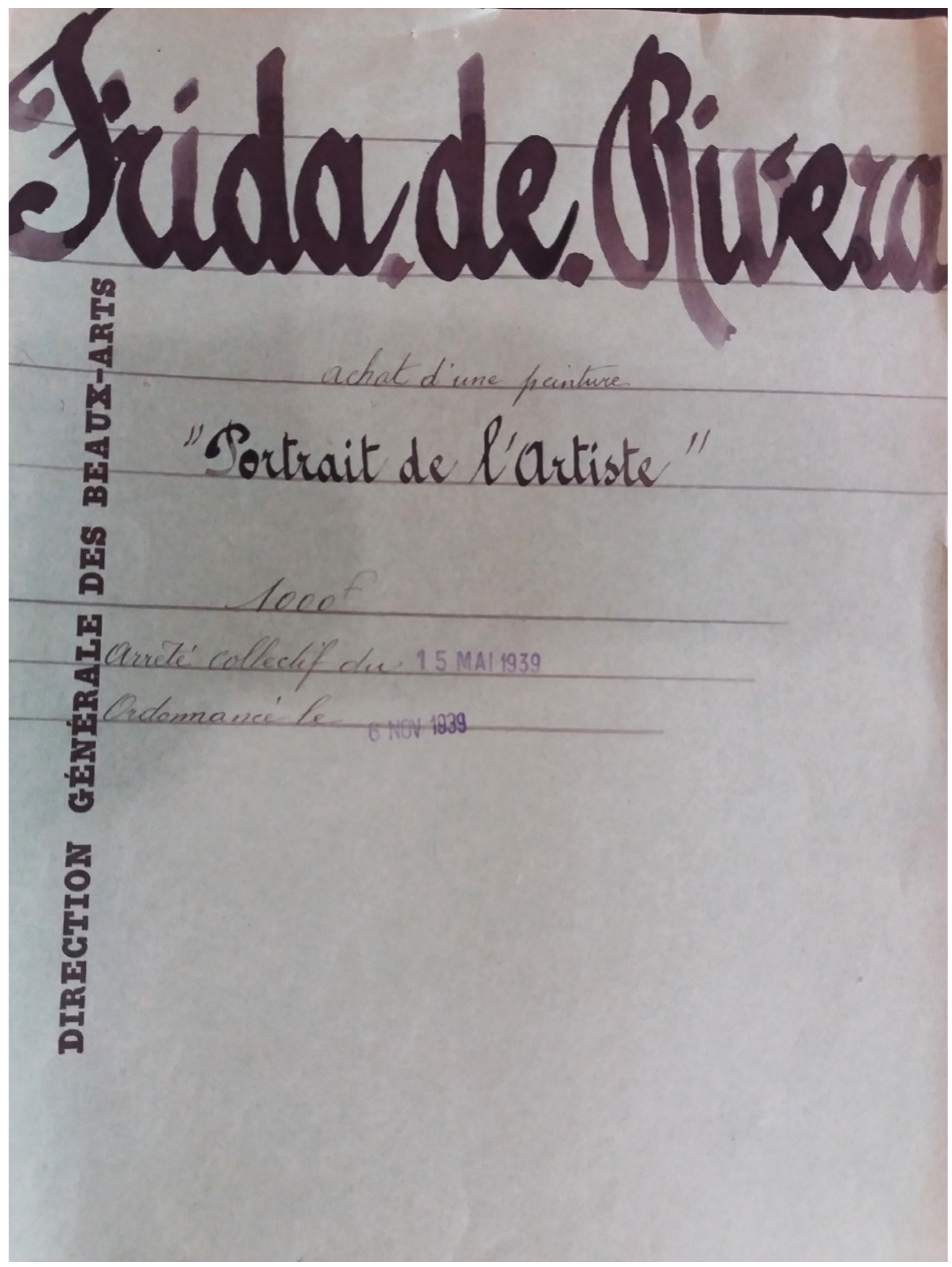

Figura 4 - Foto da capa do dossiê de Frida Kahlo. Archives Nationales. F\21 \6743. Foto: Autora. 


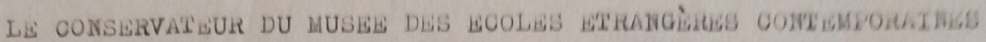

a Monsieur le Directour Général des Besux-hrta.

$2^{\circ}$ - Frida de RIVLia La formo du plus grand peintro vivant des doux Amériques, Diego Riverêa, elle-mône artiulo curieuso ot doubo, vion: d'exposer a taris, a la Galerie Renou ot Collo, nous le patronage du poète André breton, des oeuvres de caractère surróbiliate, doat quelques unes sont charmantes, not arment un portrăt d'elle-mêmo, qu'avant de quitter Paris elie laisserait uux collections du Jeu de Paume, où 1 'art méxicain est pour ainsi dire inexistant, jour la. somme de 1.000 eranas.

J'ai l'homeur de vous proposer cette acquisition.

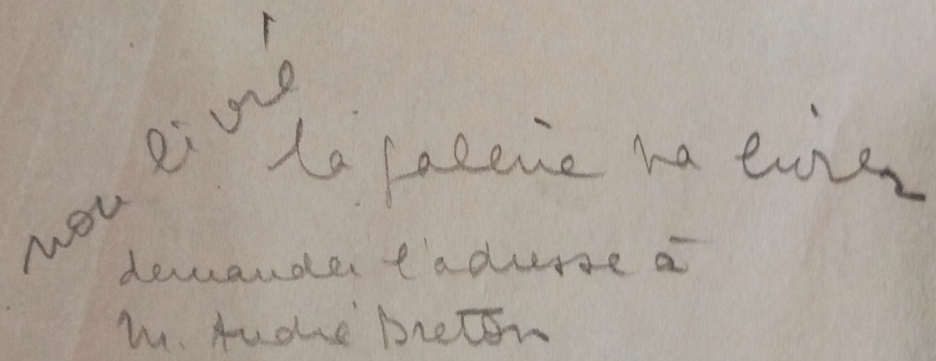

Figura 5 - Parecer assinado por André Dezarrois sugerindo a compra de obra de Frida Kahlo. Pasta/dossiê de Frida Kahlo- F\21\6743. Archives Nationales. Foto: Autora.

No entanto, são poucos os artistas latino-americanos cuja documentação referente às obras musealizadas trazem pareceres como os de Frida Kahlo. Esses, de algum modo, sinalizam a obtenção do tão sonhado "nome próprio" no campo artístico. Pode-se citar outros casos, como os de Carlos Castellanos, Vicente do Rego Monteiro e ainda Di Cavalcanti, cuja compra de Scénes bresiliènnes foi proposta também por André Desarroiz, em 1939, com vistas a enriquecer a coleção do Musée du Jeu de Paume com uma obra do Brasil, país que foi 
apontado por ele como praticamente ausente dos acervos (Figura 6). Porém, diversos outros processos dos Archives Nationales não possuem nada além da capa - são dossiês vazios. Em geral eles possuem um elemento em comum: estão ligados ao já mencionado Salon du Franc.

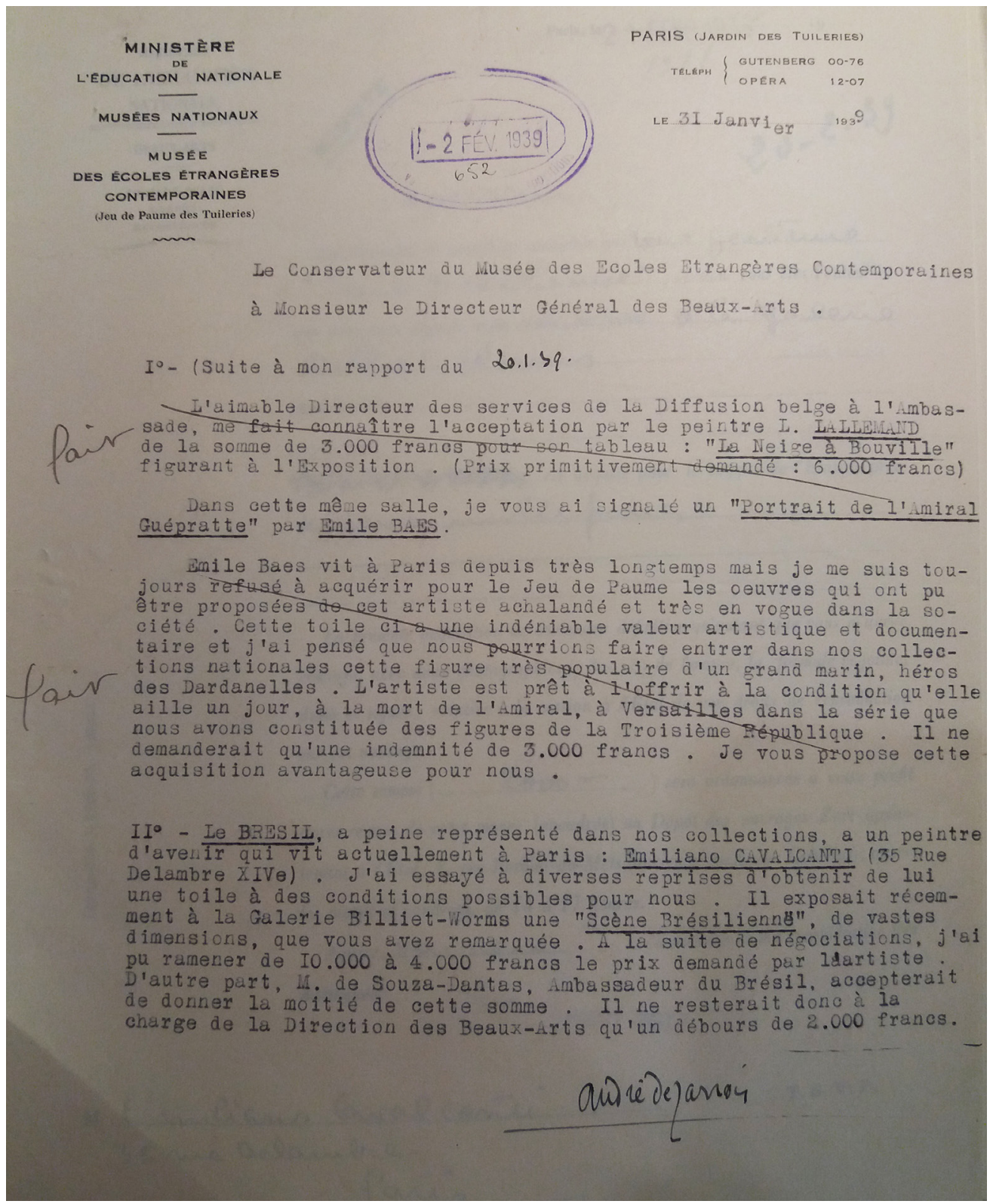

Figura 6 - Parecer assinado por André Dezarrois recomendando a aquisição de uma tela de Di Cavalcanti, Scène Brésilienne. Archives Nationales Dossiê/Pasta de Di Cavalcanti. F\21 \6730. Foto: autora. 
43. Waleffe (1926, n.p., tradução nossa). No original: "Paris est habité par les peintres et sculpteurs du monde entier. Quand ils sont dévenues célèbres, ils croient avoir vers la France une dette intelectuelle. L'appel du Maréchal Joffre pour la contribuition volontaire à la défense financière du sol français a provoque chez eux un grand élan".

\section{O SALON DU FRANC}

Entre os 28 artistas mencionados na Tabela 1, onze tiveram obras expostas no Salon du Franc. $\bigcirc$ evento foi realizado em 1926 no Palais Galliera, congregando 142 artistas provenientes de 36 países e contou com o patrocínio do jornal Paris-Midi, além de receber o apoio de diversas embaixadas e consulados. Salon du Franc foi um evento coletivo de caráter benemérito em que as pinturas e esculturas expostas tiveram seus valores de venda convertidos para o benefício da França. $\bigcirc$ objetivo era colaborar na reconstrução do país, que vivenciava ainda as consequências do pós-Primeira Guerra Mundial. Algumas obras ali expostas foram doadas para instituições francesas, enriquecendo suas coleções e, como se pretende aqui sugerir, também prestigiando seus doadores. No prefácio do catálogo assinado por Maurice de Waleffe, secretário da imprensa da Europa Latina e América do Sul, o autor afirma que:

Paris é habitada por pintores e escultores do mundo inteiro que aqui vem estudar. Quando eles se tornam célebres, crêem ter contraído para com a França uma dívida intelectual. $\bigcirc$ apelo do Marechal Joffre pela contribuição voluntária à defesa financeira do solo francês provocou neles um grande élan. ${ }^{43}$

comitê organizador do salon foi presidido pelo artista sueco Rolf de Maré, sendo ainda composto por Waleffe, seu vice-presidente, e por um secretário, o artista português Canelas da Silva Quilhôa. $\bigcirc$ comitê foi assistido para a venda das obras pelo sr. Schoeller, responsável pela galeria Georges Petit. $\bigcirc$ evento contou ainda com o apoio de diversas autoridades políticas e culturais francesas, como o Ministro das Relações Estrangeiras, o directeur de Beaux Arts, Paul Léon; além de personalidades do grand monde, representantes de fortunas internacionais, como o barão austríaco Eugène de Rothschild; a senhora Reginald Vanderbilt; a colecionadora italiana Marquesa Casati, entre outros.

Pode-se compreender o Salon du Franc como uma resposta ao texto de Warnod, mencionado no começo deste artigo dedicado à Escola de Paris e que fora publicado apenas um ano antes. $\bigcirc$ autor se referira ao modo como os artistas estrangeiros poderiam saldar as dívidas assumidas para com a "pátria artística" que os acolhera e estimulara. Segundo o catálogo, tal dívida seria saldada por meio do entusiasmo na participação nessa empreitada que, até onde se saiba, foi o único evento no período a ter esse caráter assumidamente benemérito. 
Entre os 142 artistas presentes, muitos eram russos, alemães, belgas, poloneses, espanhóis, italianos etc. Havia também alguns latino-americanos: os peruanos Luis Alberto Acuña, Jean Manuel Cardenas Castro e Carmen Sacco; os mexicanos Benjamin Coria e Ángel Zárraga; os uruguaios Carlos Alberto Castellanos e Pedro Figari; e, ainda, os brasileiros Toledo Piza, Anita Malfatti e Tarsila do Amaral. Estavam eles ao lado de nomes de grande sucesso naquele momento como Foujita, que assinou a vinheta do catálogo, Chagall, Van Dongen, Juan Gris e algumas mulheres como Alice Halicka, Chana Orloff, Maria-Mela Muter, entre outras. Certamente, suas participações no salon demonstram que gozavam de boa reputação nos meios franceses, alguma inserção e respeitabilidade, e, também, de que aquiesciam com a ideia de que nutriam uma dívida para com a França.

No entanto, essa doação pode ter trazido ganhos não apenas para os receptores, mas para os próprios doadores. A consulta às pastas dos artistas brasileiros nos Archives Nationales, em especial às de Anita Malfatti e Tarsila do Amaral, tornou perceptível que foi justamente graças a esse salon que ambas passaram a ter obras em coleções públicas francesas, o que significa que passaram também a serem mencionadas na documentação oficial. Ambos os dossiês estão, entretanto, vazios, trazendo, na capa, apenas a informação sobre a proveniência da obra (Salon du Franc), sem imagens, documentos ou notas.

Já no caso de Tarsila, as informações mais minuciosas sobre a obra estão disponíveis apenas no Museu de Grenoble. Por meio da documentação ali arquivada, compreende-se que a tela ali intitulada Composition (na verdade, a Cucal foi fruto de uma doação da artista, e não de uma aquisição, como por vezes se acredita. ${ }^{44}$ Trata-se de um gesto estratégico, pois, por meio dele, a artista logrou incluir uma de suas obras numa coleção pública francesa. A doação ao Salon du Franc constituía, assim, uma boa (e rara) oportunidade de inserção que tais artistas souberam aproveitar. As aquisições de obras de arte moderna por compra praticamente inexistiam nos anos 1920, tornando-se um pouco mais relevantes nos anos 1930, durante o Front Populaire. Mas não havia como, obviamente, o grande contingente de latino-americanos atuantes na década de 1920 preverem que os anos posteriores seriam mais amistosos às aquisições onerosas - doar era, portanto, uma excelente estratégia naquele momento para obter inserção nas coleções públicas.

As doações feitas por colecionadores eram até mais raras que as feitas por artistas, pois pressupunham três condições indispensáveis: a existência de obras junto à uma coleção privada (mas poucos gozavam dessa possibilidade); de um doador que quisesse se desfazer de obras suas em prol das coleções públicas; e,
44. Esse aspecto já tinha sido mencionado por Amaral (2003, p. 248-249). 
finalmente, que as comissões dos museus julgassem as obras oferecidas por um colecionador como de interesse público.

Nesse sentido, oferecer trabalhos para o Salon du Franc surgiu como uma oportunidade quase coletiva para os estrangeiros poderem doar suas obras e as verem aceitas pelos museus públicos. Esse atalho era capaz de oferecer um elemento de prestígio, que os artistas poderiam mobilizar em suas carreiras e que se tornava relevante em seus países de origem, signo do sucesso alcançado no exterior.

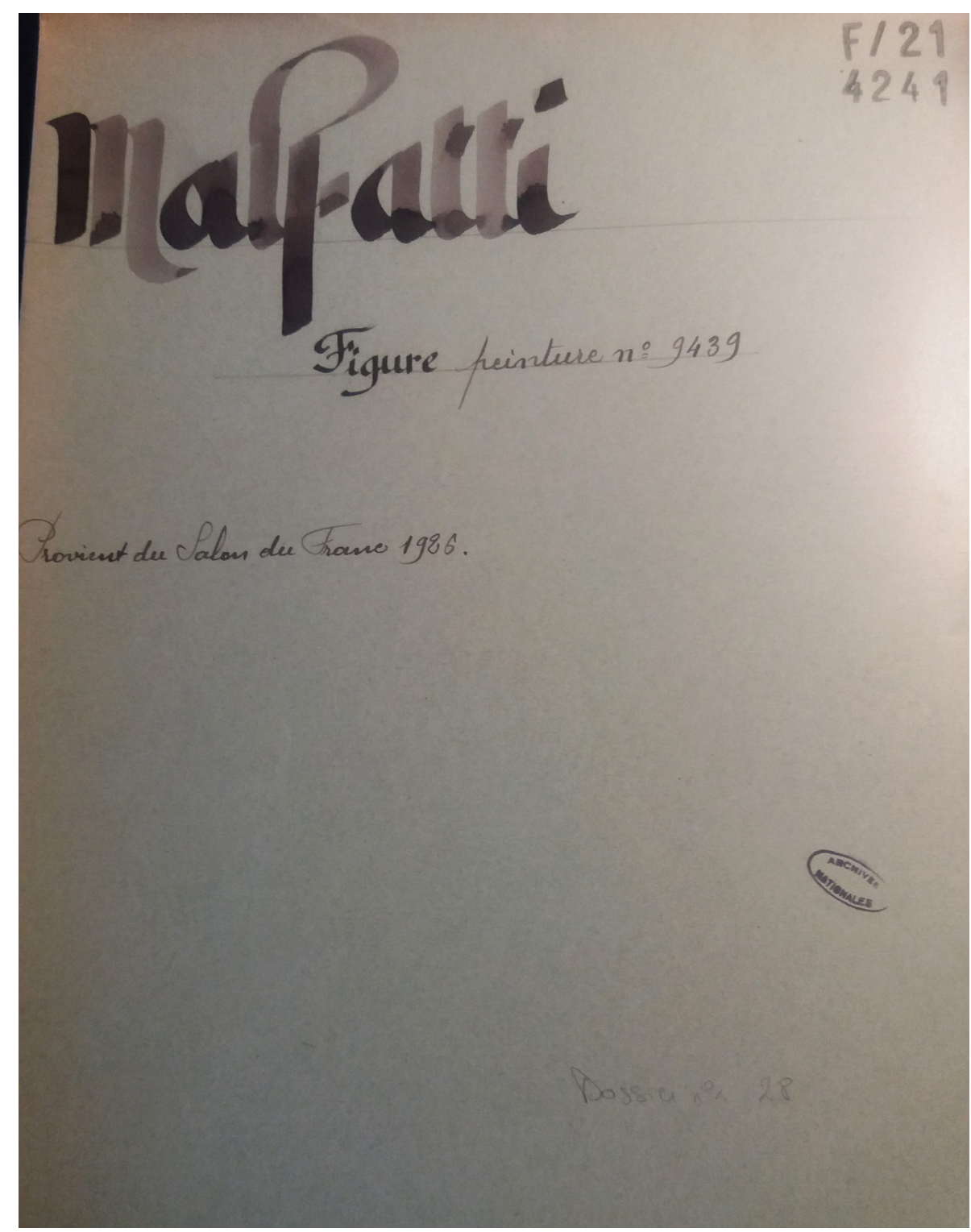

Figura 7 - Pasta do dossiê de Anita Malfatti. Archives Nationales. Detalhes: abaixo, direita, manuscrito: "Dossiê vide". Archives Nationales. F/21/4241. Foto: Autora. 


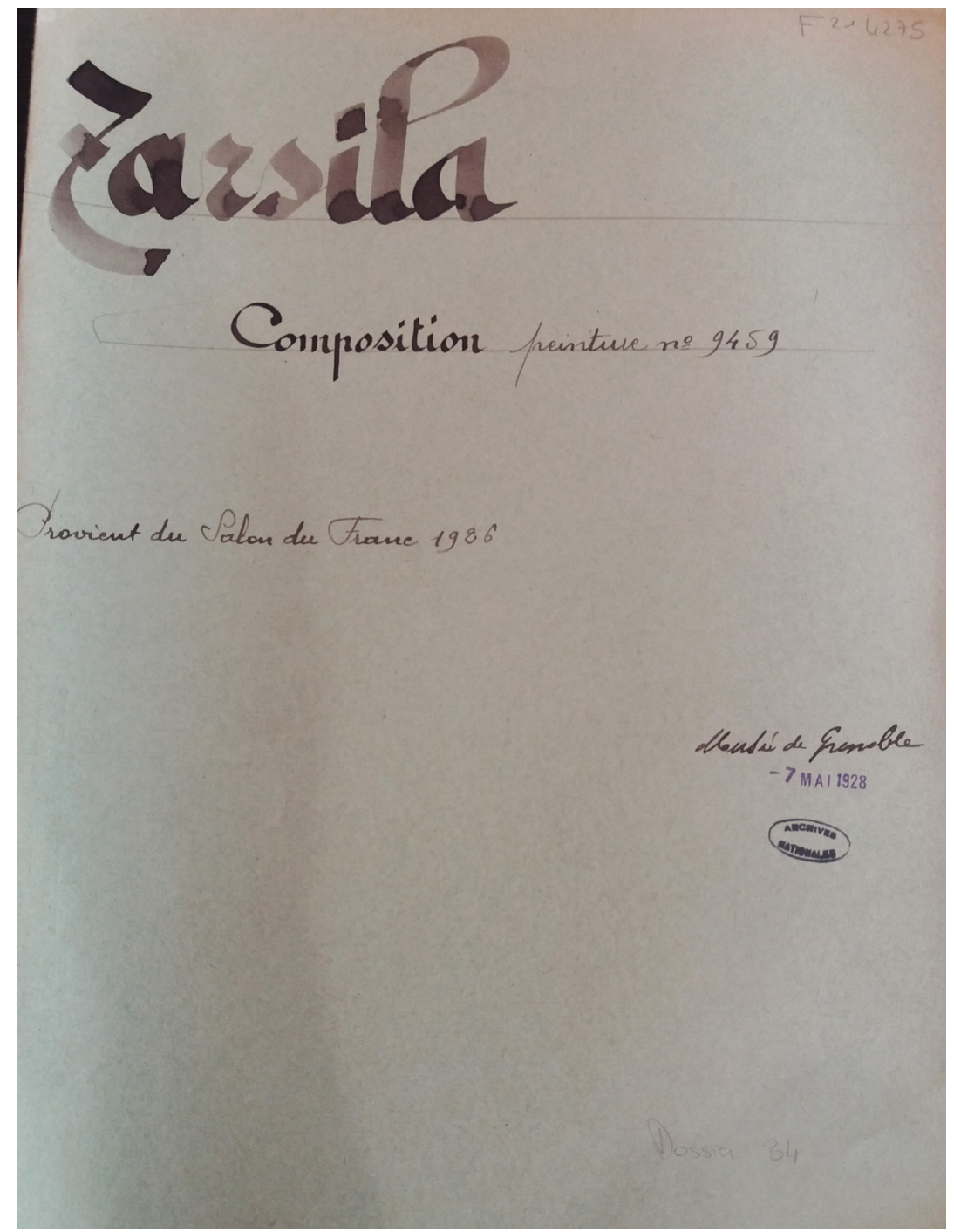

Figura 8 - Capa do dossiê/pasta de Tarsila do Amaral. Archives Nationales. $\mathrm{F} \backslash 21 \backslash 4725$. Foto: Autora.

Infelizmente, as pastas de artistas atreladas ao Salon du Franc estão completamente vazias, não sendo algo exclusivo a Anita e Tarsila. Não há pareceres, textos críticos ou quaisquer outras notas em tais processos, o que inviabiliza análises mais aprofundadas sobre os trâmites e manifestações de mérito sobre tais doações.

Salon du Franc é um episódio menor na história da arte francesa, sendo raramente lembrando ou até mesmo mencionado nos estudos sobre salões do período; não obstante, para a história dos artistas latino-americanos na França tratase de um evento nada negligenciável, cuja compreensão mais aprofundada esbarra hoje, porém, no caráter lacunar das fontes disponíveis. 
45. A revista Art Vivant foi uma das mais importantes no contexto francês dos anos de 1920. Ela começou a ser editada em 1924 por Florent Fells, e deixou de ser publicada em 1939. Segundo Béatrice Joyeux-Prunel, era uma das três principais revistas de arte da França: "Trois revues comptaient pour l'actualité artistique parisienne dans l'entre-deux-guerres : L'Amour de l'art (fondé en 1920), L'Art vivant (1925) et les Cabiers d'Art (1926). Toutes trois d'apparences similaires (format $4^{\circ}$, une quarantaine de pages de textes et des reproductions), elles se distinguaient par leur périodicité (mensuelle pour les deux derniers, bihebdomadaire pour L'Art vivant), leur prix (L'Art vivant étant moins cher), donc par le public qu'elles visaient - et par l'art qu'elles soutenaient. Elles ne favorisaient pas particulièrement l'innovation". Joyeux-Prunel (2017, p. 49).

46. Michaud (1996).

47. Léonce Bénédite, historiador da arte, foi diretor do Musée du Luxembourg entre 1892 e 1925.

48. A revista o apresenta como "critique d'art, marchand de tableaux; fondateur de la revue Der Querschnit. Proprietaire de galeries d'art à Dusseldorf, Berlin, Cologne, Francfort".

\section{A PRESENÇA DOS ARTISTAS LATINO-AMERICANOS NO MUSÉE NATIONAL D'ART MODERNE (1942/1947)}

Desde os anos 1920, discutia-se a necessidade de se criar um museu dedicado especialmente à arte moderna na França. Em 1925, por exemplo, a revista Art Vivant15 promoveu uma pesquisa junto a artistas, críticos, colecionadores, intelectuais e comissários de museus, que então respondiam às duas perguntas estabelecidas pelo periódico: (1) se se fazia necessária a criação de um museu dedicado à arte moderna?; (2) quem seriam os dez primeiros artistas a terem obras adquiridas pela instituição? 46

A enquete foi uma reação à crise do Musée du Luxembourg, deflagrada com o processo de sucessão de seu diretor, Léonce Bénédite. ${ }^{47}$ Desde o início, a situação dessa instituição estava um tanto incerta, pois por vezes era percebido como "um museu de passagem", posto que, após dez anos do falecimento do artista, suas obras ali expostas deveriam ser transpostas para o Louvre, onde permaneceriam definitivamente. A fragilidade do Luxembourg se acentuou à medida em que sua política aquisitiva continuou a seguir o "gosto oficial" durante as primeiras décadas do século XX, quando a Academia já perdera muito de sua importância. Com o falecimento de Bénédite, em 1925, criou-se uma ocasião propícia para discutir o devir do museu.

Havia duas questões em jogo por trás da ideia de um museu de arte moderna francesa. Em primeiro lugar, o termo moderno. Como definir o que seria a "art vivant"? $\bigcirc$ problema não era simples. Como escolher as obras mais representativas do presente, diante de uma tão grande pluralidade de estilos e escolas? Para aqueles mais afinados com as prerrogativas da arte moderna, boa parte da produção adquirida pelo museu nos últimos decênios era uma arte ultrapassada que só perpetuava uma tradição vista como obsoleta. Para outros, porém, a produção que seguia os cânones da Escola de Belas Artes congregava o verdadeiro saber fazer, que escapava das regras do presente, vistas como simples modismo.

Em segundo lugar, e não menos importante, impunha-se a questão de quem deveria estar representado no museu de arte moderna francesa. Essa era uma questão sensível ao menos desde 1922, quando as obras de artistas estrangeiros do Musée du Luxembourg foram alocadas no Musée du Jeu de Paume e passaram a ter um lugar para si; já que a produção contemporânea francesa de orientação modernista ainda não possuía um espaço próprio, como vimos anteriormente. Além disso, acreditava-se que as obras modernas francesas de melhor qualidade haviam sido adquiridas por colecionadores ou instituições estrangeiras e, por conseguinte, não mais estariam no país. Os comentários do galerista Albert Flechtheim ${ }^{48}$ são primorosos nesse sentido. Diz ele: 
O amante da arte estrangeiro vem a Paris para estudar a arte contemporânea, não encontrando nada nos museus, deve percorrer a rua La Boétie ou a rua Laffitte para saber o que ocorre em seu país. Nos museus, ele encontra os impressionistas, mas nenhuma tela de Seurat. As pinturas de nossa época só são encontradas com os marchands.

Os museus alemães já começaram a adotar a pintura contemporânea antes de 1914. Matisses podem ser encontrados no Museu Folkwang em Hage, entretanto foram transportados recentemente para Essen, Frankfurt e Munique; há Derain em Colônia e Essen; Vlaminks em Barmen, Elbferld, Colônia, Bremen, Hamburgo; bronzes de Maillol no Folkwang de Munique, Ulme e na Galeria Nacional de Berlim.

Acaba-se de comprar um Georges Braque para o Museu de Essen, um Juan Gris para o de Colônia, um quadro de Marie Laurencin para o Museu d'Ulm (Danúbio), alguns Pascin para os museus de Bremen, Dusseldorf, Dresden e alguns Vlamincks para Dortmund, Dusseldorf.

Minha opinião é: um museu de arte francesa contemporânea é absolutamente necessário caso a França queira conquistar o mundo inteiro para os artistas vivos.

Cabe aos franceses julgar quais artistas deveriam entrar primeiro na coleção. Mas creio que os artistas adquiridos para nossos museus, e alguns outros ainda, em primeiro lugar - Henri Rousseau, Georges Rouault, Mauriece Utrillo, Fernand Léger - esses não deveriam faltar. ${ }^{49}$

relato aponta o quanto a arte moderna francesa estava sendo vendida para o exterior, em países que já haviam iniciado um processo de sua institucionalização, criando museus de arte moderna muito antes da França, processo esse que estava particularmente avançado na Alemanha. Flechtheim assinala explicitamente que um interessado em arte moderna só poderia encontrar as obras de vanguarda nas galerias de arte e, portanto, expostas apenas temporariamente. Era urgente criar um museu de arte moderna em Paris, e caberia "aos franceses" escolherem "seus artistas".

$\bigcirc$ crivo nacional marcava, com efeito, o debate. A lista obtida pelas respostas dos entrevistados pela revista Art Vivant é sugestiva. Os artistas mais votados para figurarem no museu a ser criado foram: Henri Matisse (26 votos); André Derain (20); André Dunoyer de Segonzac (19 votos); Pablo Picasso, Pierre Bonnard, Aristide Maillol, Maurice Utrillo (1 8 votos cada); Antoine Bourdelle, George Braque ( 14 votos cada); Vlaminck e Georges Rouault ( 13 votos cada)..$^{50}$ Apenas dois estrangeiros são lembrados entre os mais importantes, Pablo Picasso, e, em uma posição mais baixa, Van Dongen que, por sinal, adotara a nacionalidade francesa. ${ }^{51}$

Todavia, somente muitos anos depois o Musée National d'Art Moderne viria a ser efetivamente inaugurado. Desde a década de 1930, durante o governo do Front Populaire, diversas aquisições foram feitas visando a compor a coleção do futuro museu, que estava previsto para ser inaugurado em 1937, durante a Exposição Internacional que seria sediada em Paris. Com efeito, duas construções
49. Flechtheim (1925 apud MICHAUD, 1996, p. 68-69, tradução nossa). No original: L'amateur étranger venant à Paris pour étudier l'art contemporain, n'en trouvant pas dans les musées, doit parcourir la rue La Boétie ou la rue Laffitte pour voir ce qui se passe chez vous. Dans les musées, il trouve des impressionnistes, mais aucun tableau de Seurat.

Les peintres de notre époque ne se trouvent que chez les marchands.

Les musées allemands ont déjà commencé à adopter de la peinture contemporaine avant 1914 . On trouve des Matisses dans le musée Folkwang de Hage, transporté entre temps à Essen, à Francfort et à Munich; des Derain à Cologne et à Essen, des Vlaminck à Barmen, Elberfeld, Cologne, Brême, Hambourg; et des bronzes de Maillol dans le Folkwange, à Munich, Ulm et dans la Galerie National de Berlin.

On vient d'acheter un Georges Braque pour le musée d'Essen, un Juan Gris pour le musée de Cologne, un tableau de Marie Laurencin pour le musée d'Ulm (Danube), des Pascin pour les musées de Brême, Dusseldorf, Dresde et des Vlaminck pour Dortmund, Düsseldorf.

Voilá mon opinion:

Un musée d'art français contemporain est absolument nécessaire, si la France veut conquérier pour des artistes vivants le monde entier. C'est aux Français à juger quels artistes doivent y entrer les premiers. Mais je crois que les artistes achetés par nos musées et quelques autres encore - en premier lieu Henri Rousseau, Georges Rouault, Maurice Utrillo, Fernand Léger - ne devraient pas manquer". 
50. Para mais detalhes, Cf. Michaud (1996, p. 170-171).

51. O outro único artista estrangeiro que aparece na lista dos trinta primeiros lugares é Kees Van Dongen, com seis votos obtidos. É importante notar que cada entrevistado podia apontar até dez nomes.

52. Georges Huisman, que era republicano e judeu, foi substituído por Louis Hautecoeur junto à Direction des Beaux Arts, o que significou também a substituição de um partidário do modernismo por um diretor de orientação mais conservadora. Cf. Ory (1994, p. 817-818).

53. Bertrand Dorléac (2017, p. 121, tradução nossa). No original: "C'est au coeur de 1942 que le Musée d'Art Moderne ouvre ses portes à la surprise générale, présentant un tiers environ de ses collections d'oeuvres contemporaines demeurées à Paris ou ramennés de province pour la circonstance [...]".

54. Bertrand Dorléac (2017, p. 122).

55. O livro da autora aborda aprofundadamente a questão da retomada da tradição artística francesa, dentro de uma perspectiva nacionalista, durante o período que vai de 1939 a 1944.

56. Bertrand Dorléac (2017, p. 122-123).

57. Diz-se primeiro ensaio pois essa primeira configuração do Musée National d'Art Moderne ficou aberta entre agosto de 1942 e abril de 1944 , depois só reabriria definitivamente em 1947. gêmeas imponentes foram vislumbradas desde 1924 no Quai Tokyo, com vistas a inauguração do Musée National d'Art Moderne ao lado do Musée d'Art Moderne de la Ville de Paris. Porém, os projetos de instalação tiveram de ser adiados em razão da deflagração da Segunda Guerra Mundial e das profundas limitações que seriam impostas à população francesa.

Entre os anos de 1939 e 1944, a França foi ocupada pela Alemanha. Com a mudança radical de regime, diversos dos nomes atuantes durante 0 governo do Front Populaire viram-se alijados de seus cargos, fosse por sua participação direta na guerra, pelo afastamento de seus postos e/ou por sua atuação contra o Estado colaboracionista. ${ }^{52}$ Os sonhos de fundação do museu foram interrompidos. Todavia, em 1942, uma versão do que seria o Museu de Arte Moderna foi inaugurada às pressas, com vista a evitar a ocupação do espaço pelas autoridades alemãs, que desejavam transformar o local em um depósito de armas. Segundo Laurence Bertrand Dorléac, no verão de 1942, "o Musée de l'Art Moderne abre suas portas, para surpresa geral, apresentando em torno de um terço de suas coleções de arte contemporânea [...]".53 $\bigcirc$ Palais de Tokyo viu surgir uma exposição de arte francesa organizada por Louis Hautecoeur, nomeado por Pétain para substituir Georges Huisman como Directeur des BeauxArts, auxiliado pour Pierre Ladoué e Bernard Dorival, conservadores chefe e adjunto, respectivamente, do Musée National d'Art Moderne. ${ }^{54}$

Embora não tenha sido possível localizar um catálogo-guia publicado nessa ocasião, o livro de Dorléac traz uma lista dos artistas expostos, a partir de textos publicados na imprensa, os quais foram considerados representativos da "tradição artística francesa". ${ }^{55}$ Foram eles: Yves Alix, Asselin, Bissière, Bonnard, Braque, Brianchon, Céria, Chapelain-Midy, Chastel, Maurice Denis, Derain, Dunoyer de Segonzac, Charles Dufresne, Friesz, Goerg, Gruber, Gromaire, La Fresnaye, Lapicque, Lautrec, Fernand Léger, Legueult, Lhote, Lurçat, Marquet, Matisse, Pignon, Rohenr, Rouault, Roussel, Tanguy, Vallotton, Vuillard, Walch, Waroquier. E, no campo da escultura, Bacque, Belmondo, Bourdelle, Bouret, Delamarre, Despiau, Drivier, Gasq, Gaumont, Gimond, Maillol, Pommier, Pompon, Jeanne Poupelet, Puech, Wléric e Yencesse. .56

O conjunto comporta somente artistas franceses. Nomes emblemáticos da escola de Paris, como Picasso, Gris, Modigliani, Foujita, Chagall, Soutine, entre tantos outros, estavam excluídos. É também interessante perceber que apenas uma mulher artista foi escolhida para constar no conjunto: a escultora Jeanne Popuelet. Na primeira inauguração do Museu Nacional de Arte Moderna para a França, sob os auspícios do governo de Vichy, estrangeiros e mulheres não pareciam ser bem-vindos. ${ }^{57}$ 
Com o fim da guerra, em 1945, antigos servidores públicos franceses foram reconduzidos a seus empregos e alguns projetos que haviam sido abortados foram retomados. Esse é o caso, por exemplo, de Jean Cassou que, após vários anos participando da Resistência, foi promovido a responsável pela condução do Musée National d'Art Moderne, tornando-se seu primeiro diretor após a inauguração oficial, em 1947. Ele já havia, nos anos 1930, acompanhado de perto um processo de modernização das coleções francesas, encomendando obras ou incentivando a compra por parte do Estado de diversos artistas modernos, muitos estrangeiros inclusive, com vistas à inauguração do museu em 1937, que não ocorreu pelos motivos expostos.

Finalmente, em 9 de junho de 1947, o Musée National d'Art Moderne abria suas portas na ala oeste do Palais de Tokyo, a partir da fusão das coleções de Écoles Étrangères reunidas no Musée du Jeu de Paume com a coleção contemporânea francesa até então pertencente ao Musée du Luxembourg. Nele permaneceu até 1977, quando foi transferido para sua sede atual, o Centre Georges Pompidou. É interessante perceber que a França inaugurava seu primeiro museu modernista praticamente ao mesmo tempo em que esses surgiam na "retardatária" América Latina. Em Santiago do Chile, o Museo de Arte Contemporáneo foi inaugurado em 1947, em um edifício conhecido como El Partenón de Quinta Normal. ${ }^{58}$ No Brasil, o Museu de Arte Moderna de São Paulo e seu congênere no Rio de Janeiro foram inaugurados em 1948. Na Argentina, o Museo de Arte Moderno de Buenos Aires foi fundado em 1956.59 Já no México, o Museu de Artes Plasticas, sediado no Palacio de Bellas Artes, expunha desde 1947 artistas mexicanos contemporâneos, especialmente os vinculados ao muralismo, como Siqueiros, Rivera e Orozco. No entanto, essa integração se dava em chave nacionalista, de ode aos heróis nacionais representados nas pinturas murais. O Museu Nacional de Arte Moderna foi inaugurado efetivamente em 1958.60

A inauguração do MNAM, em 1947, era um marco, concretização de um projeto coletivo nutrido desde os anos 1920. Mas estariam os latino-americanos presentes nessa importante ocasião? Em 1947, cerca de 3 mil obras foram exibidas ao público, a maior parte delas provenientes das aquisições do Estado realizadas anteriormente. Essas foram acrescidas por algumas poucas inclusões feitas durante os anos da Ocupação, e algumas doações de peso foram feitas pelos próprios artistas em 1947. Entre elas a de Picasso é emblemática, composta por cerca de onze telas desse artista tão consagrado, mas que possuía uma ínfima presença institucional. ${ }^{61}$ Além dele, o pintor russo Marc Chagall doou sete telas, outro caso de artista com grande reputação e pouca presença de obras nas coleções
58. Agradeço à Gloria Cortes Alliaga por essa informação.

59. Agradeço à Marita Garcia e Maria Isabel Baldasare pela ajuda com essa informação.

60. Agradeço à Dafne Porchini; Ana Garduño e Deborah Dorotinsky pelas precisões. A respeito do México, Cf. Porchini et al. (2016); e Garduño (2011).

61. A esse respeito ler: Musée National d'Art Moderne (2017). 
62. Tais doações foram propositalmente fomentadas pelo diretor Jean Cassou que, ao assumir o posto em 1945 , procurou preencher os buracos da coleção. Conforme seu testemunho: "Depuis octobre 1945, date à laquelle je suis rentré dans cette maison, j'ai tenu à combler les lacunes qui existaient encore, en particulier en ce qui concerne quelque-uns des maîtres reconnus de l'art moderne. Bonnard et Vuillard se trouvaient dèjà fort bien représentés au musée. [...] Mais l'effort principal a dû porter sur Matisse, qui n'y était représenté que par trois peintures, Braque qui ne l'était que par trois, Rouault que par deux. Tous ces grands artistes ont compris mon fervent désir de servir cet art authentique, cet art vivant, cet art français qu'ils avaient, durante toute leur carrière, illustré malgré le dédain des pouvoirs publics, et on témoigné pour mon enterprise la plus empressée bonne volonté. Il en a été de même de Picasso, qui, par un geste magnifique, a, en mai 1947, fait don à la France de dix de ses toiles, choisies parmi les plus importantes et les plus significatives". Musée National d'Art Moderne (1947, p. III-IV).

63. Musée National d'Art Moderne (1947, p. V-VI, tradução nossa). No original: "[...] Le présent, tel qu'en donne l'image le Musée d'Art Moderne, commence à l'Ecole de Pont-Aven et aux successeurs de Gauguin ainsi qu'aux Néo-Impressionnistes et aux successeurs de Seurat. Puis les galeries ouvertes de plain-pied au visiteur racontent à celuici la succession des écoles, les inventions, des maîtres caractéristiques et significatifs. Le rez-de-chausée bas est consacré à la sculpture, ainsi qu'à une rétrospective de ce riche fourmillement de talents et d'oeuvres qu'ont produit les divers Salons, richesse d'autant plus vive francesas. Em ambos os casos a atuação de Jean Cassou foi essencial para preencher lacunas das coleções então existentes. ${ }^{62}$

O catálogo-guia do Museu, publicado na ocasião, nos permite conhecer as disposições das salas, os artistas e as obras presentes em cada uma delas. A organização do museu é bem explicada pelo prefácio assinado por Cassou:

O presente, cuja imagem é dada pelo Museu de Arte Moderna, começa na Escola de Pont-Aven e os sucessores de Gauguin e, os neoimpressionistas e sucessores de Seurat. Depois, as galerias abertas no mesmo nível dizem ao visitante sobre a sucessão de escolas, as invenç̃es, os mestres característicos e significativos. $\bigcirc$ piso inferior é dedicado à escultura, bem como a uma retrospectiva deste rico enxame de talentos e obras que os vários salões produziram, riqueza cada vez mais viva posto que é contraditória e se apresenta como o fruto de um intenso e fecundo debate. Um espaço nesta parte do museu foi dedicado aos estilos e modas dos anos 1900. No primeiro andar, finalmente, o visitante encontra a expressão das gerações mais recentes. A fim de tornar vivo todo esse conjunto, mistura-se a pintura, e a escultura às obras decorativas, conjuntos de móveis, tapeçarias, produtos em vidro, cerâmica, etc. E para torná-lo instrutivo, dispôs- se na maior parte das vitrines das salas documentos que evocam a imagem e o destino de certos artistas, o clima em que ele produziu sua obra, as circunstâncias e as modas do tempo a viram nascer, as aproximações estéticas que ela suscita. ${ }^{63}$

Otexto traz algumas considerações sobre a narrativa pretendida pelo museu e seus impasses. Como esclarece Cassou, havia o desejo de distribuir as obras e os artistas a partir de uma perspectiva evolutiva, segundo a qual os movimentos e escolas artísticas se sucederiam no tempo, demonstrando suas "invenções" lou rupturas) sucessivamente. Tal narrativa era muito semelhante àquela adotada por Alfred Barr para o MoMA, a qual pretendeu organizar, segundo uma visão etapista, os movimentos artísticos a partir da ideia de autonomização, tendo como ápice a abstração. No entanto, essa perspectiva, em si complicada por ser restritiva e teleológica, não poderia ocorrer do mesmo modo na França. Sabe-se que a abstração jamais foi um consenso na Escola de Paris; aliás, pelo contrário. Além disso, se havia o desejo de construir uma narrativa totalizante, como o texto aponta, era preciso também dar conta de um acervo preexistente. Esse compreendia um conjunto de obras muito diverso, composto por aquisições feitas desde o início do século XX pelo Musée du Luxembourg, de feitio mais tradicionalista. A essas somavamse as obras pertencentes ao Musée du Jeu de Paume e, finalmente, aquelas escolhidas diretamente pelas comissões incumbidas da criação do MNAM, que haviam atuado antes da Ocupação e que retomaram os trabalhos em 1945. O primeiro andar da mostra manifestava esse ecletismo, ao dividir as salas não por critérios estilísticos, mas sim por proveniência. Havia assim a sala das obras herdadas do Salon de la 
Nationale, do Salon d'Automne e do Salon des Indépendants. A disposição desse conjunto vasto, complexo e heterogêneo pelas salas do museu acaba por dificultar uma narrativa clara e unidirecional, como a pretendida pelo MoMA.

Das mencionadas três mil obras expostas na inauguração do MNAM em 1947, 623 artistas estavam ali representados. $\bigcirc$ número é grandioso, mas as exclusões são também reveladoras. Em texto recente, apontei o quanto as mulheres artistas estiveram pouco representadas nesse momento, totalizando apenas 45 nomes, o que significa menos de 10\% do total de artistas expostos. ${ }^{64}$ Muitas artistas mulheres hoje notáveis, cujas obras foram adquiridas durante os anos 1930 e 1940, poderiam ter sido escolhidas, dentre elas Frida Kahlo, Tamara de Lempicka, Sonia Delaunay e Maria Helena Vieira da Silva, apenas para citar algumas. Mas todas as citadas têm dois pontos em comum: são mulheres e estrangeiras; variáveis que se sobrepõem. A exclusão é ainda mais impressionante quando pensamos na variável nacionalidade latino-americana. Simplesmente nenhum(a) artista latino-americano, homem ou mulher, foi selecionado(a) para figurar na inauguração do MNAM. E, vale lembrar, a essa altura o Estado possuía obras de Frida Kahlo, Tarsila do Amaral, Rego Monteiro, Ángel Zárraga, Alberto Lagos, Toledo Piza, Pedro Figari e outros.

O prefácio assinado por Jean Cassou apontava como um dos principais objetivos do novo museu a superação entre a divisão entre escolas nacionais e estrangeiras, mas na prática isso não parece ter ocorrido. Diz o autor:

O Musée des Écoles Étrangères, que algum dia esteve atrelado ao Jeu de Paume, agora o é a meu departamento. [...] Mas para o que é da Escola Francesa propriamente, ou seja, École de Paris, eu não estabeleço nenhuma distinção entre os artistas franceses da França e os que, de origem estrangeira, foram ou não foram naturalizados franceses. Uns e outros, ao lado uns dos outros, têm seu lugar nessa sala consagrada ao movimento de pintura francesa, a que eles aportaram a contribuição de seus talentos. Estarão, portanto, nas salas de escolas estrangeiras aqueles artistas que levaram suas vidas e suas carreiras em seus próprios países, participando de sua vida espiritual. ${ }^{65}$

Diante de uma afirmação tão clara sobre a presença ombreada dos artistas franceses e estrangeiros na mesma instituição, uma tomada de posição certamente em contraposição aos dogmas nacionalistas que foram predominantes durante o período da Ocupação, como explicar a ausência mencionada de artistas latino-americanos? É verdade que alguns artistas estrangeiros estiveram representados nessa exposição inaugural, afinal o catálogo traz os nomes de Foujita, Modigliani, Alice Halicka, Marie Blanchard, Zadkine, Chana Orloff entre qu'elle est contraditoire et se présente comme le fruit d'un incessant et fécond débat. Une salle, dans cette partie du musée, a été consacrée aux styles et aux modes de l'époque 1900. Au premier étage, enfin, le visiteur trouve l'expression des générations plus récents. Afin de rendre vivant tout cet ensemble ou a mêlé la peinture et la sculpture d'oeuvres décoratives, ensembles mobiliers, tapisseires, verrerie, céramique, etc. Et pour le rendre instructif on a disposé dans la plupart des salles des vitrines de documents évoquant la figure et le destin de tel artiste, le climat dans lequel il a produit son oeuvre, les circonstances et les modes du temps qui la vit naître, les rapprochements esthétiques qu'elle suscite".

64. Sobre a diferença na presença feminina nos museus de arte moderna em tempos de fundação, particularmente entre o MoMA e o MNAM, Cf. Simioni (2019).

65. Musée National d'Art Moderne (1947, p. V-VI, tradução nossa). No original: "Le Musée des Ecoles étrangères, qui se tenait autrefois au Jeu de Paume, a été rattaché à mon département. [...] Mais pour ce qui est de l'Ecole française même, c'est-à-dire de l'Ecole de Paris, j'ai tenu a n'établir aucune distinction entre les artistes français de France et ceux qui, d'origine étrangère, avaient été ou n'avaient pas été naturalisés français. Les uns et les autres, à côté les uns des autres, ont leur place dans telle salle consacrée au mouvement de peinture française auquel uns comme les autres apportèrent la contribuition de leur talent. Ne se trouveront donc dans la salle des écoles étrangères que les artistes qui ont mené toute leur carrière dans leur pays et exclusivement participé à la vie spirituelle de celui-ci". 
outros(as). $\bigcirc$ critério utilizado parece ter sido o da reputação alcançada nos meios parisienses, embora isso não esteja dito em lugar algum.

Musée National d'Art Moderne conferia, no discurso (e não na prática), pesos equivalentes aos termos "nacional" e "arte moderna". Ou seja, nele a origem dos artistas, e não apenas sua contribuição particular para um léxico modernista internacional, contava. Naquele universo competitivo destacar-se como artista estrangeiro e, particularmente, proveniente da América Latina eram conquistas notáveis. Como vimos aqui, embora Paris tenha sido apontada diversas vezes como uma pátria para os artistas latino-americanos, as possibilidades de reconhecimento foram bastante reduzidas, restringindo-se a alguns poucos nomes solares que lograram ter obras nas coleções públicas. E mesmo esses não foram vistos como brilhantes o suficiente para figurarem no templo de consagração da arte moderna que se ergueu, depois de muitas expectativas e investimentos, em 1947. Os dados indicam que, ao fim e ao cabo, a Escola de Paris e sua suposta abertura à contribuição de todos (as) estrangeiros (as) foi um mito acolhedor; mas ainda assim... um mito. 


\section{REFERÊNCIAS}

FONTE MANUSCRITA

MALFATTI, ANITA. Carta para Mário de Andrade. Paris, nov 1926. Arquivo do Instituto de Estudos Brasileiros da Universidade de São Paulo, Acervo Mário de Andrade. Correspondência passiva. Código: MA-C-CPL4508

LIVROS, ARTIGOS E TESES

AMARAL, Aracy. Tarsila, sua obra e seu tempo. 3. ed. São Paulo: Edusp: Editora 34, 2003.

BAL, Danièle; FARCY, Pierre-André. Andry-Farcy, un conservateur novateur. Le Musée de Grenoble 1919 à 1949. Grenoble: Le Musée de Grenoble, 1982.

BATISTA, Marta Rossetti. Os artistas brasileiros na escola de Paris: anos 1920. São Paulo: Editora 34, 2012.

BERTRAND DORLÉAC, Laurence. Histoire de l'art. Paris 1940-1944: ordre national, traditions et modernités. Paris: Publications la Sorbonne, 1986.

BERTRAND DORLÉAC, Laurence. L'École de Paris: un problème de définition. Revista de História da Arte e Arqueologia, Campinas, n. 2, p. 249-271, 1996.

BOWNESS, Alan. The condition of success: how modern artists rises to fame. New York: Thames and Hudson, 1989.

CAMARGOS, Marcia. Entre a vanguarda e a tradição: os artistas brasileiros na Europa (19121930). São Paulo: Alameda, 2011.

COTA JR, Eustáquio Ornelas. A formação da coleção latino-americana do MoMA. São Paulo: Paco Editoral, 2019.

FURIÓ, Vicenç. Arte y reputación: estudios sobre el reconocimeinto artístico. Barcelona: Memoria Artium, 2012. 
GARDUÑO, Ana. Acervos in construción, museus expandidos. Cimientos, 65 años del INBA, Mexico, DF, p. 12-39, 2011.

GREET, Michele. Transtlantic encounters: Latin American artists in Paris between the wars. New Haven: Yale University Press, 2018.

GREET, Michele. An international proving ground: Latin American artists at the Paris Salons. Nuevo Mundo Mundos Nuevos, [s. l.], 6 jun. 2017. Disponível em: <https://bit.ly/3vjQhZf>. Acesso em: 20 ago. 2020.

GONNARD, Catherine; LEBOVICI, Élisabeth. Femmes artistes/artistes femmes, Paris de 1880 à nos jours. Paris: Éditions Hazan, 2007.

GUILBAUT, Serge. How New York stole the idea of Modern Art: abstract expressionism, freedom, and the Cold War. Chicago: University of Chicago Press, 1983.

HEINICH, Nathalie. Le triple jeu de l'Art Contemporain. Paris: Éditions Minuit, 1998.

JOYEUX-PRUNEL, Béatrice. L'art de la mesure. Histoire E Mesure, Liège, v. 22, n. 1, p. 145-182, 2007.

JOYEUX-PRUNEL, Béatrice. Les Avant-Gardes Artistiques (1918-1945): une histoire transnationale. Paris: Folio, 2017.

KANGASLAHTI, Kate. Foreign artists and the École de Paris: critical and institutional ambivalence between the wars. In: ADAMSON, Natalie; NORRIS, Toby (eds.). Academics, pompiers, official artists and the arrière-garde: defining modern and traditional in France, 1900-1960. Cambridge: Cambridge Scholars Publishing, 2009. p. 85-111.

LE MUSÉE DE GRENOBLE. Andry-Farcy, un conservateur novateur: Le Musée de Grenoble 1919 à 1949. Grenoble: Musée de Grenoble, 1982.

LES CAHIERS du Musée Nationale d'Art Moderne. Paris: Centre Pompidou, 2018.

LETHÈVE, Jacques. La vie quotidienne des artistes français au xixème siècle. Paris: Librarie Hachette, 1968.

MAINGON, Claire. L'âge critique des salons, 1914-1925: l'école française, la tradition et l'art moderne. Rennes: Presses Universitaires de Rennes, 2014. 
MAROJA, Camila. Modernités Plurielles 1905-1970. Arte E Ensaio, Rio de Janeiro, n. 27, p. 212-215, 2013.

MICHAUD, Yves. Préface. In: MOREL, Jean-Paul. Pour un musée français d'art modern: une enquête de L'Art Vivant en 1925. Paris: Réunion des Musées Nationaux, 1996. p. 11-19.

MORA, Maira; PARKMANN, Fedora. " Modernités plurielles »: quelle décolonisation du regard? Hypothèses, [s. l.], 23 abr. 2015. Disponível em: <https://bit.ly/2NgQeMC>. Acesso em: 6 jan. 2021.

MUSÉE D'ART MODERNE DE LA VILLE DE PARIS. L'École de Paris, la partie de l'autre. Paris: Musée d'Art Moderne de la Ville de Paris, 2000.

MUSÉE NATIONAL D'ART MODERNE. Catalogue-guide. Paris: Musées Nationaux, 1947.

MUSÉE NATIONAL D'ART MODERNE. Picasso 1947: un don majeur au Musée National d'Art Moderne. Paris: Éditions du Centre Pompidou, 2017.

ORY, Pascal. La belle illusion: culture et politique sous le signe du Front Populaire, 1935-1938. Paris: Plon, 1994

PORCHINI, Dafne et al. Recuperación de la memoria histórica de exposiciones de Arte Mexicano (1930-1950). Mexico DF: UNAM, 2016.

QUEMIN, Alain. Les stars de L'Art Contemporain: notoriété et consécration artistiques dans les arts visuels. Paris: CNRS Éditions, 2013.

ROJZMAN, Nuria Peist. El proceso de consagración en el arte moderno: trayectorias artísticas y círculos de reconocimiento. Matèria, Barcelona, n. 5, p. 17, 2005.

SAINT-RAYMOND, Léa; MAUPEOU, Félicie de; CAVERO, Julien. Les rues des tableaux: géographie du marché de l'art parisien (1815-1955). Artl@s Bulletin, Paris, v. 5, n. 1, 2016.

SIMIONI, Ana Paula Cavalcanti. Modernas em museus: a consagração tardia, In: PEDROSA, Adriano; CARNEIRO, Amanda; MESQUITA, Andre (orgs.). História das mulheres, histórias feministas: antologia. São Paulo: MASP, 2019. p. 483-499. 
SIMIONI, Ana Paula Cavalcanti. Mulheres modernistas: trajetórias de consagração na arte brasileira. 2018. Tese (Livre Docência em Sociologia da Arte) - Instituto de Estudos Brasileiros, Universidade de São Paulo, São Paulo, 2018.

SOARES, Gabriela Pellegrino. A América Latina e as ressignificações simbólicas do espaço. Entre as dinâmicas das identidades e as temporalidades da História. Calibán, Brasília, DF, v. 13, p. 164-171, 2015.

SQUEFF, Leticia. Originalidade e modernidade na arte latino-americana: a Exposição de Arte Latino-Americana [Exposition d'art Américain-Latin] de Paris (1924). In: COLÓQUIO LABEX BRASIL-FRANÇA, 2016, São Paulo. Anais [...]. São Paulo: MAC-USP; Paris: Université Paris Ouest, 2015. p. 250-268.

WALEFFE, Maurice de. Préface. In: SALON du Franc. Paris: Palais Galliera, 1926. Não paginado.

SITES

ARCHIVES NATIONALES. Base de données Arcade. Archives Nationales, Paris, 2020. Disponível em: <https://bit.ly/3cLbCCA>. Acesso em: 19 mar. 2021.

JACONDE. Documentation. Jaconde, [s. l.], 2020. Disponível em: <https://bit.ly/3lwPn75>. Acesso em: 19 mar. 2021.

TRANSATLANTIC ENCOUNTERS. Latin American artists in interwar Paris. Transatlantic Encounters, [s. l.], 2020. Disponível em: <https://bit.ly/30V4wWs>. Acesso em: 19 mar. 2021.

PASTAS DOS ARTISTAS CONSULTADOS NOS ARCHIVES NATIONALES

Acuna, Luis Alberto - F/21/4163

Tarsila do Amaral - F/21/4500B; F/21/4275

Anita Malfatti - F/21/4241

Barreda, Enrique - F/21/4168 e F/21/4910/A

Beltran-Masses, F. - F/21/6970

Candido Portinari - F/21/6849 [Recusado. Documento em restauro]* 
Cardenas Castro - F/21/4185

Carreño, Mario - F/21/6974

Castellanos, Carlos - F/21/4185

Coria, Benjamin - F/21/4191

Di Cavalcanti - F/21/6730

Diego Rivera - F/21/6850

Gaston de Fonseca - F/21/4208; F/21/6742

Lagos, Alberto - F/21/4229

Lasar Segall - F/21/6788

Toledo Piza - F/21/6724

Pedro Figari - F/21/4208

Rego Monteiro, Vicente do - F/21/6760; F/21/6939; F/21/6936

Rendon, Manuel - F/21/4262

Rozo, Romulo - F/21/4267

Sangroniz, Luis A.- F/21/4340

Sacco, Carmem - F/21/4268

Sicre, Juan - F/21/4271

Rufino Tamayo - F/21/6946

Terry, Juan - F/21/4276

Joaquim Torres-Garcia - F/21/6946

Valenzuela Llanos, Alberto - F/21/4344; F/21/4238

Zarate Ortis, Miguel - F/21/4888; /21/ 4285

Zárraga, Ángel - F/21/6996; F/21/4285; F/21/6776

Artigo apresentado em: 20/08/2020. Aprovado em: 10/02/2021.

\section{(c) BY}

All the contents of this journal, except where otherwise noted, is licensed under a Creative Commons Attribution License 